HStud 27 (2013)1, 15-66

DOI: 10.1556/HStud.27.2013.1.2

\title{
DEALING WITH DICTATORSHIP: THE US AND HUNGARY DURING THE EARLY KÁDÁR YEARS
}

\author{
LÁSZLÓ BORHI \\ Institute of History of the Hungarian Academy of Sciences \\ Budapest, Hungary \\ E-mail: 1borhi@indiana.edu
}

Because of the legacy of 1956 the hardest country to engage behind the iron curtain was Hungary. The history of the Hungarian political amnesty, a milestone in the development of the most liberal system in the Soviet bloc is an anatomy of the hurdles of diplomacy in dealing with a closed dictatorship under the sway of a foreign power. The new Soviet-installed government launched massive reprisals against real and alleged participants of the revolution. For the first time the US was able to influence events in a Soviet controlled country through diplomatic efforts exerted in the UN. In 1962 after years of difficult negotiation the leaders in Budapest agreed to amnesty political prisoners in exchange for the removal of the Hungarian Question. The settlement was in the best interest of the Hungarians. The regime's international position was an embarrassment for Moscow. Hungary was internationally isolated. That the deal was so long in the making showed the difficulty of dealing with a client state supported by a world power. The political committee's view of world matters was formed by the tenets of communist ideology. This and the knowledge that they would be backed by the Soviet Union through thick and thin allowed the Hungarians to adopt a rigid and uncompromising stance. They exploited domestic weakness to garner support in a conflict that Moscow was ready to settle. Kádár expected American officials to deal with Hungary as a proud independent national entity. Communist functionaries struggled to understand the motivations of American policy. American diplomats found it hard to strike the right tone when dealing with their communist counterparts. Also they did not know about the inner power struggle behind the facade of communist unity. The Kádár regime's eventual willingness to strike a deal and put an end to domestic terror had to do with his desire to launch the country on a road to economic modernization. This required a gradual and limited opening to the West. One of the pillars of this new policy would be the normalization of relations with the US. Prudently the State Department made it known that this would not happen until political prisoners were freed.

In the meantime US goals in Eastern Europe went through drastic change. This was matched by a new approach to the Soviet bloc. The liberation of Eastern Europe and the reunification of the continent were deemed unfeasible. Therefore a more moderate aim of "continental re-association" was adopted. In fact the restoration of the independence of states in Eastern Europe no longer seemed an unequivocally more preferable condition than the Soviet control of middle Europe. Rather than destabilizing them as in the fifties the US became interested in the consolidation of more liberal communist regimes as a prerequisite of western security. In other 
words as opposed to the doctrine of the 50 s western security no longer required the restoration of national independence. Liberation and containment was replaced by the doctrine of bridge building. This aimed at the gradual transformation of communist regimes to more liberal and more autonomous albeit not independent or fully democratic entities within the tolerance limit of the Soviets. By the early seventies the European status quo was "not so bad" for the Americans. The East Europeans' only hope for liberation would be change within the Soviet Union.

Keywords: 1956, reprisals, UN, Hungarian Question, Hungarian mandate, amnesty, liberation, containment, bridge building, reassociation, autonomy, national independence, western security

Democratic powers have always faced recalcitrant rogue states, and often presumed that the right set of policy pressures could force these contrarian nations to comply with civilized codes of conduct, domestically and internationally. It is often forgotten that even such states have domestic, bureaucratic struggles - disagreements between agencies and decision-makers with divergent agendas. Such states are often nationally self-conscious entities that demand respect from the international community, and thus whose actions are conditioned by foreign pressures and unforeseen events. Accordingly, there is no single, "correct" policy for any regime. Transformations require patience, flexibility, and the quickness to adapt to changing circumstances. When to give in and when to tighten the reigns, how much to expect in a given situation, how to sound out the vulnerabilities of the opponent, and how to avoid to blackmail: problems and dilemmas like these are rarely recognized as factors in international affairs.

The United Nations had been conceived as a supranational organization that would transcend narrow national interests to uphold international harmony. Instead, it became a forum in which the interests of the two superpowers and the blocs they represented were to collide. The UN was incapable of stopping Soviet aggression in Hungary, but, perhaps surprisingly, it became an efficient tool with which to exert pressure on the Kádár regime to bring its bloody rampage of terroristic reprisals to an end.

Shortly after Marshall Konev launched the final assault on Budapest, the UN decided to suspend its decision on the Hungarian mandate in the world organization. Subsequently, on January $10^{\text {th }} 1957$, the General Assembly formed a fact-finding committee to explore the Hungarian situation in the hope of sending a UN mission to Budapest. A separate proposal, to reject the Hungarian mandate (which would have meant the country's ejection from the world organization), was not accepted due to fears it could serve as a precedent for excluding Taiwan, which the USSR had refused to accept as the legitimate representative of mainland China. Nevertheless, domestic opponents accused the Eisenhower adminis- 
tration of a double standard, of doing less against the aggressor in Eastern Europe than the ones (Israel, France, and Great Britain) in the Middle East.

Even so, the taking up of the Hungarian question and the suspension of the Hungarian mandate isolated the Kádár regime. In the international arena, Kádár's government was forced to concentrate on resolving the Hungarian question, restoring its full status in the UN, and breaking out of its status as an international pariah. This was not a new predicament for Hungarian foreign policy: the country had experienced similar situations in the aftermath of both World Wars. For the United States, the question was whether the Hungarian government was willing to take concrete steps toward a domestic détente. To maximize the pressure, Washington questioned the Soviet-installed regime's legitimacy. In addition to the impasse in the UN, Hungarian-American relations were also complicated by a number of other, interrelated issues, which meant that US contacts with Hungary took place at a lower diplomatic level than its relations with other people's democracies. One such issue was the seemingly intractable problem of Cardinal Mindszenty. Until the problem of his presence in the US embassy in Budapest was resolved, talks on the settlement of financial claims could not even begin. Such efforts were already under way with Romania. Moreover, diplomatic contacts were stuck on the legation level. The new minister, Edward Wailes, had arrived at his post as Soviet tanks were rolling into the Hungarian plain. He had had no time to present his credentials to the Nagy government before it was overthrown, and did not do so afterward. When the UN General Assembly acted on a US proposal to suspend Hungary's mandate, the Hungarian Foreign Ministry asked Wailes to present his credentials or leave the country. Wailes opted for the latter and departed within four days. Nobody suspected that a decade would pass before his successor was appointed. Thus bilateral relations had again reached a nadir. Almost all contact ceased, even at the grass-roots level. Diplomats avoided each other in the corridors of the United Nations; "contacts" were restricted to the mutual expulsion of military attachés; the Hungarian chargé was not received at the State Department for months. Political pressures drove the business community to boycott Hungary, which led Paprikás Weiss, a popular delicacy store in New York, to seek State Department approval to import Hungarian salami. American passports were invalid for Hungary, thus almost no one embarked on the trip across the ocean.

In their own way, the Hungarians also created tensions, sometimes seemingly ready to take things to the breaking point. In reality, Budapest would stop at the edge of the precipice, just short of breaking off relations. In May 1957, at the instigation of the Ministry of Interior and the counter-intelligence service, the Hungarian Foreign Ministry demanded that the US Legation reduce its staff of diplomats and administrative personnel. ${ }^{1}$ The pretext was that "the American employees are illegally collecting intelligence instead of nurturing relations". ${ }^{2}$ The Hungarians 
then offered to exchange ministers, ${ }^{3}$ but to nobody's surprise this offer was rejected. Dulles would allow minor gestures only to support steps towards the relaxation of tensions and to nurture the peoples' spirit of resistance. This included the relaxation of travel restrictions and a token expansion of cultural exchanges. ${ }^{4}$ The chargé in Budapest opposed the exchange of heads of mission on the grounds that it would entail the acceptance of the Hungarian mandate and the easing of economic controls; at the same time, he saw no chance for UN resolutions to be implemented in Hungary. ${ }^{5}$ Austria's foreign minister, the future chancellor Bruno Kreisky, who would eventually build a special " $\mathrm{K}$ und $\mathrm{K}$ " relationship with Kádár, offered to mediate negotiations with the regime in Budapest. When Kreisky asked what conditions they would have to fulfill for the sake of normalization, he was told that the Hungarians needed to comply with UN resolutions, admit UN representatives to the country, grant safe passage to Mindszenty, and make peace with the Hungarian people - conditions the chargé in Hungary considered exaggerated. ${ }^{6}$ By the end of 1957 , tensions subsided somewhat when it became apparent that the regime in Hungary would last.

Kádár managed to eliminate the Central Workers' Council, his main rival for the hearts and minds of the working class. Meanwhile, his Stalinist foe Rákosi was kept in Moscow, and the chief ideologist of Hungarian Stalinism, József Révai, was neutralized. Most importantly, Kádár won Khrushchev's firm support. ${ }^{7}$ The head of the State Department's Bureau of East European Affairs pointed out that the regime in Budapest was on its way toward domestic and international consolidation. Internationally, the Revolution was fading into oblivion, and it was doubtful whether international pressure could do anything to liberalize the system. He therefore recommended a more flexible course, one more readily adaptable to existing conditions. ${ }^{8}$ On the first anniversary of the Revolution, Eisenhower made clear that no one in the higher echelons of power had contemplated any radical changes in US policy. In response to the president's address, Hungarian Foreign Ministry officials recommended that diplomatic relations with the US be severed, but Kádár rejected such a drastic measure. Instead, a harshly worded note was drafted calling on US leaders to refrain from supporting "counter-revolutionary elements". However, the Soviets prevented the message from being sent. ${ }^{9}$ Moscow exercised restraint, an approach Washington did not expect.

Another push towards normalization came from a rather unexpected quarter. The Hungarian chargé in Washington, Tibor Zádor, a relatively junior diplomat who had distinguished himself in his proclamations of support for Kádár, now advocated "steps towards normalization of relations" with the United States in order to "reduce the intensity of the hostile campaign and improve relations with other Western states". He recommended the release of the Hungarian employees of the US Legation, and a "revision" to the quantitative controls on American 
personnel. This diplomat was also in favor of further steps, including an exchange of statements by high-level functionaries; he primarily recommended diplomatic channels and the use of the legation in Washington in pursuing a policy of normalization. ${ }^{10}$ On his own initiative, Zádor met Senator Malone with the intention of expanding trade relations. ${ }^{11}$ Zádor used the modest means at his disposal to break out of his isolation, although some of his efforts may have done more harm than good. These included film screenings at the legation. One of his movies was meant to show that "the situation is quite normal and the traces of the counter-revolution were disappearing", but since such a film "obviously" did "not exist", the legation staff pieced one together from some older footage and borrowed a screen from the Romanians. This short film was named "Hungary 1957", but the Hungarian desk officer at the State Department had justifiable doubts about its authenticity. It was also subject to question whether an audience of American businessmen, lawyers, and diplomats would appreciate scenes like "Workers' Meetings in Budapest", "The Formation of the Workers' Militia", "Ho Chi Minh's Visit", and the like. "Unforgettable April", a film about the visit of "the Soviet Party and Government Delegation" to Budapest, screened on a different occasion, was probably equally successful. ${ }^{12}$

In 1958, the Hungarian Foreign Ministry, which had showed at least some interest in improving relations with the US, perceived a positive shift in the American attitude toward Hungary, which they hoped to exploit. For the sake of improvements, they made a list of possible measures taking into account mutual grievances. On the Hungarian side these included the closing of the consulates in 1951, the "propaganda campaign" against the Hungarian government including Radio Free Europe, and the lack of economic contacts. The foreign ministry recommended that the Hungarian government make known that it would be receptive to an overture and simultaneously release the US Legation's imprisoned employees. ${ }^{13}$ The Hungarian security apparatus won this round of the contest: as soon as the employees in question were released, they were immediately relocated to the countryside. At that point the Foreign Ministry was under the close direction of the Hungarian Socialist Workers' Party's Department of International Relations, so there is no doubt that its recommendations represented the ideas of at least some top leaders.

The international climate favored improvements. Khrushchev launched a peace offensive, and although he made it clear that he would not negotiate on Eastern Europe, he pulled Soviet troops out of Romania and at least one division out of Hungary. Romania made good use of this window of opportunity. Party leader Gheorghe Gheorghiu-Dej invited Americans to observe Romanian elections and in 1958, his government announced that it would purchase 100 million dollars' worth of industrial equipment from the US. The National Security Council noted that Romania was prepared to expand its commercial ties and to 
arrange limited cultural, scientific, and technical exchange programs. In 1960, the Battle Act was modified to allow the president to extend economic aid to communist countries if it could be justified by national security, and in March of that year, Romania concluded an agreement to settle outstanding financial claims with the US. An exchange of notes would launch exchange programs between the two countries in 1962, by which time Washington was no longer treating Romania like the "most Sovietized" satellite. ${ }^{14}$

On January $25^{\text {th }}$, 1958, the Political Committee of the HSWP discussed the normalization of Hungarian-American relations and the settling of the Hungarian question at the UN. Foreign Minister Sík gave a speech in Parliament on April $2^{\text {nd }}$ in which he announced that he would take an initiative to repair ties with the US. On May $8^{\text {th }}$, he told the American chargé, Garret Ackerson, that he had been thinking of exchanging ministers, but that the initiative had been cancelled. Ackerson knew Hungary well. He had worked at the US Legation in the 1930s and had compared the current state of Hungarian affairs unfavorably with the country he had known under Horthy. Sík had studied in Moscow in the 1930s and lived through the Great Terror, which left an indelible imprint on his psyche. His memoir, published in the 1970s, recounts that while he was third secretary in the Hungarian legation in Washington, he made a trip to New York during which the police stopped his car in Central Park after dark. Sík was terrified of the American authorities, convinced that he would disappear and lose his life. Now, the foreign minister was claiming that his initiative had been rescinded because the Hungarian mandate had been rejected during the Maritime Law Conference in Geneva and because the US representative to the UN, James Wadsworth, had demanded information on the whereabouts of the leaders of the Hungarian Revolution. Ackerson pointed out that both events had occurred after Sík had announced his diplomatic initiative. ${ }^{15}$ Its cancellation was all the more surprising since Sík had informed Soviet Foreign Minister Andrei Gromyko of his proposed action on April $7^{\text {th }}$, and Gromyko had approved it. ${ }^{16}$

US diplomats suspected that Khrushchev might have been behind the cancellation of the initiative, but in light of the foregoing, this seems unlikely. The minutes of the Khrushchev-Kádár talks contain no reference to it. In his conversation with Ackerson, Sík hinted that the Foreign Ministry had had nothing to do with the relocation of the legation's employees, and the fact that Sík needed Béla Biszku's permission to relax travel restrictions suggests that the Ministry of the Interior may have intervened. Sík made reference to this via metacommunication: Ackerson recorded that during their conversation, Sík nodded towards the Interior Ministry building on the opposite bank of the Danube. This would indicate that the process of formulating foreign policy was more complicated than the Americans suspected. The Soviets did not interfere in relatively minor matters; the two rival ministries were simply pursuing the same 
goal by different means. In the 1950s, the Ministry of the Interior would win battles like this even though the foreign minister was part of the old guard that had returned from Moscow.

The Foreign Ministry suspected that the State Department no longer considered it just to "punish the Hungarians for the Soviet intervention" and to continue rejecting overtures. ${ }^{17}$ If this idea had any real basis, it would be soon dispelled. The execution of Imre Nagy and his associates on June $16^{\text {th }}$, 1958 put an end to the lukewarm and sluggish process of improvement. These executions outraged the administration and US diplomats made it clear that relations would turn for the worse. This also meant that the Hungarian question would be kept in the limelight at the UN. On July $11^{\text {th }}$, State Department officials consulted with their British and French ambassadors on the rejection of the Hungarian mandate and possibly even the rupture of diplomatic relations with Budapest. ${ }^{18}$ The drastic step was not ultimately taken, but the latest American offensive at the UN caused a great headache in Hungary. The Political Committee prepared an offensive of its own: they wanted simultaneously to "unmask" American espionage and to show that Nagy's execution was the outcome of legal procedures against the participants of the 1956 revolt. In this debate, Prime Minister Ferenc Münnich called the American Legation a "spy center" and declared they could "go home if they want". The eminence grise of Hungarian foreign policy, a party historian named Dezső Nemes, did not think it "useful" to sever diplomatic relations. ${ }^{19}$ The anti-American campaign would include two more steps. There would be a government press conference on September $12^{\text {th }}$ to denouncing American espionage against Hungary. Then Budapest would present a diplomatic note offering to participate in a dialogue if the US "ceased hostile propaganda and spying against the country". ${ }^{20}$ Hungarian leaders were trying to legitimize their terror campaign by alleging threats from a dangerous foreign enemy. The Foreign Ministry's unveiling of an American "spy center" in front of a large audience invoked the atmosphere of the show trials, though now the "defendant" was a foreign state.

The State Department was in no hurry to reply. Six months passed before the Hungarians were told that normalization would occur if they were to adhere to their commitments to the UN and to the terms of the peace treaty. ${ }^{21}$ In the meantime, US diplomacy was working feverishly to reject the Hungarian mandate, even though China's membership in the organization would require a two-thirds majority. In this critical situation, the foreign minister initiated the second part of his "diplomatic offensive", announcing to the General Assembly that judicial proceedings against "counterrevolutionaries" had been closed and terminated. US ambassador to the UN Henry Cabot Lodge Jr. immediately declared that to his knowledge, four other leaders of the uprising had just been convicted. ${ }^{22}$ The "offensive" was thus defeated and the Hungarian question was inscribed on the agenda of the $13^{\text {th }}$ General Assembly. By rejecting the 
Hungarians' mandate, the State Department wanted to draw world attention to communist reprisals there and thereby to deal a psychological defeat on the Soviet Union. ${ }^{23}$ Eisenhower did not want to proceed all the way to a rejection of Hungary's membership, so the original situation remained: the Hungarian mandate was merely suspended. The General Assembly did condemn the Hungarians for executions (although the Americans erroneously held the Soviets responsible), and asked Leslie Munro to report on the implementation of the UN resolutions on Hungary.

As if this were not enough, another time bomb exploded, fraying the US-Hungarian relationship. Cardinal Mindszenty, the archbishop of Esztergom and primate of the Hungarian Catholic Church, had been held under house arrest until a Hungarian army unit - the head of which was later executed for this act - briefly liberated him in 1956 and brought him to Budapest to deliver a radio message. Sensing that he was running out of luck, he appeared at the entrance of the US Legation in the small hours of November $4^{\text {th }}$, just as the Soviet offensive on Budapest was beginning. He was admitted, and, after consultations with Washington, given asylum, even though legation personnel feared that doing so might cause the premises to be attacked. Béla Kovács, whose arrest in 1947 became a symbol of the Soviets' ill-will behind the Iron Curtain, also appealed for refugee status, but was denied. Kovács spent a number of years in Soviet captivity before serving in Imre Nagy's revolutionary government. The Hungarians understood that it was against international law and US government regulations to use diplomatic missions for asylum, but Mindszenty's presence at the US mission eventually provided unforseen opportunities to influence Hungarian politics, the likes of which did not exist in any other Iron-Curtain state.

Initially, there were only difficulties. Legation employees prepared for an assault on the building by the Hungarian police they expected them to try to abduct the cardinal. In order to minimize risks, he was barred from all correspondence other than discussions of his personal life. Nevertheless, the aged prelate would bombard senior US officials and even presidents with letters. He criticized their foreign policy. He thought it too conciliatory toward the Soviets, too accepting of the status quo in Eastern Europe, and unprincipled in its compromises with communism, a system he detested passionately. He was rarely answered. His views were taken into account in the controversy over the return of Saint Stephen's Holy Crown. Mindszenty also caused problems for the communist authorities. He was regarded as a political criminal, but charging him seemed undesirable because of the public outcry it would likely cause. Both sides took the most convenient course: they kept silent about it for as long as possible. But Mindszenty's fate was to become interlocked with Cold War politics.

The day of reckoning arrived with the death of Pius XII on October $9^{\text {th }}, 1958$. That afternoon, the US Embassy in Rome recommended that the State Depart- 
ment ask the Sacred College of Cardinals to summon Mindszenty to the papal election. Even though the State Department did not like the idea, the Embassy took the necessary steps without waiting for an answer. ${ }^{24}$ The Vatican saw a chance to get Mindszenty out, so the State Department instructed the American legation in Budapest to negotiate with the Hungarian government on behalf of the Sacred College of Cardinals. After the Vatican sent the appropriate instructions to Mindszenty, officials in Washington decided that if the Hungarians were to allow the cardinal to leave the country, they would guarantee Mindszenty's silence on political matters. A decade and a half later, the Hun- garian government would release Mindszenty on this same condition, but the time was not yet ripe in 1958.

Leaders in Budapest so hoped to extract political concessions that it took them a long time to realize that there was no chance for any. Mindszenty himself was fairly unenthusiastic about the prospect of leaving his refuge and agreed to go only after lengthy persuasion. The American note to the Hungarian authorities inexplicably failed to mention the conditions of his silence; it was restricted to the question of whether the authorities would be willing to let Mindszenty travel to the conclave in Rome. ${ }^{25}$ The reply was firmly negative. The Hungarians were not even willing to explore the possibility at that point. They pointed out that their authorities had condemned the cardinal to a life sentence for "political and other crimes" in 1956, including his escape from custody and his carrying out "criminal activity against the political order of the Hungarian People's Republic". It was also noted that the cardinal's asylum constituted a violation of international law and US government regulations, as well as an attempt to interfere in Hungary's internal affairs. Mindszenty's fate was a Hungarian matter, not "subject to Hungarian-US talks". Finally, the note made it clear that the government would "pay more attention to [the] Mindszenty question in the future". ${ }^{26}$ The legation concluded that the Hungarians were happy with the situation, or at least less uncomfortable than the US. They emphasized that their "guest" was not making things any easier and should therefore be advised to seek the Pope's "spiritual leadership", 27

The Foreign Ministry saw no link between Hungary's intransigence and the poor state of its relations with the Americans. This was attributed to the "sharply antisocialist stance of [American] leading circles", due to which only slow improvements could be expected. The resolution of the Hungarian question and the normalization of ties were expected in the longer run. ${ }^{28}$ By this time, however, there were debates in the higher echelons of the party about economic reform. This would require financial and economic assistance from the US, but it was well understood that Washington would not agree to expand economic ties until its outstanding financial claims were settled. The balance would favor the Americans. Even if Washington were to accept all Hungarian claims, including frozen assets, the restitution of Hungarian commodities, and compensation for the 
property lost on the "Gold Train", it would not match the amount owed by Hungarians for war damage to US property and nationalizations of American companies. ${ }^{29}$ Although the "Polish model" presented itself, the Foreign Ministry counseled procrastination. Poland had agreed to a financial settlement with the US using income derived from increased trade resulting from commercial incentives and long-term loans. Romania had increased its trade with the US threefold between 1956 and 1960 and agreed to settle US claims. The Hungarians must have known that Romania had signed to pay only a fraction of the original claims against it, and that Hungary could expect a similar deal. However, the necessary pragmatism and political will seems to have been missing from Budapest. $^{30}$

\section{Image in Foreign Policy}

Foreign policy is formulated not according to some objectively existing reality in the external world, but on the basis of images in the minds of the leaders of one power or another. Eventually this dependence on perception would work in favor of Kádár's Hungary. Hungary came to be pictured as the most liberal state behind the Iron Curtain, even though, to paraphrase the Nobel-prize-winning author Imre Kertész, it was "so horrible we did not even notice it". In an analysis of Eastern European satellites prepared in 1959, the CIA noted that Hungary had been consolidated to a considerable extent since 1956, and although the CIA. had been grossly mistaken three years earlier, it predicted again that mass rebellion was unlikely. ${ }^{31}$ Stability was discussed in a positive light, even though prior to 1956 it would have been seen as an unwelcome development, and pro-American sentiment was taken for granted. Senator Charles Vanik wrote that "penetration might be made in this part of the Soviet-dominated world to preserve and keep alive well-developed but silent affection for America. The hope for the restoration of democracy in this part of the world will be strengthened as a result of individual missions of American citizens visiting their relatives." ${ }^{32}$ However, the second secretary of the legation in Budapest warned American citizens travelling to Hungary that tourism behind the Iron Curtain was different from a trip to Western Europe. Tourists and people visiting family were to be aware that they were coming to a "police state", where, if they met with difficulties, they might end up at the mercy of capricious bureaucrats. ${ }^{33}$

A correspondent for ABC television named George Bailey traveled across Hungary in 1960 and claimed to have spoken with "hundreds of people". His overall impression was "depressing"; he found that people had lost faith and did not wish to get into trouble. Most of the people with whom he had spoken were initially suspicious, but after a while they tended to loosen up and begin 
condemning the Kádár regime and the country’s foreign occupation. He visited the once-upscale holiday resort of Siófok on Lake Balaton, where he saw hotels for workers so depressing that they evoked Orwell's 1984. It seemed as if everyone were wearing the same uniform and taking part in group activities like building roads. Later in Tihany, Bailey met others more like the Hungarians who lived in his memory - teachers, writers, and intellectuals who openly lambasted the regime. In the agricultural town of Makó, Bailey found beautifully kept farm animals and buildings, "but the cows were better groomed and happier than the people".

While Bailey saw the dreariness of life there, National Geographic deputy director Francis Shor focused on Hungary's standards of living. Shor randomly selected ten families, and since there were two wage-earners in each, every one of them was able to maintain "a tolerable standard of living". Shortages of goods were "annoying", but nothing that would lead to "unrest". He found housing conditions poor, but thought that people tolerated it "philosophically". Shor found, "somewhat to his surprise" (one may wonder why he would find this surprising), "a fairly substantial intellectual middle class - unhappy and by no means enthusiastic about the regime, but tending to accept it for the present". A freelance writer, Lance Wiley, found evidence that standards of living were higher than in Romania, and thus opined that the Hungarians "did win a partial victory in 1956". In contrast to Bailey, one legation officer found that the middle-class way of life had not disappeared. Hungarians went on vacation to "enjoy themselves"; only a few attended the almost compulsory lectures that had become a part of what was called 'vacationing' in other bloc countries. He found "much greater resistance [in] the Hungarians to forced indoctrination" than in other communist countries. When Feld visited the scenic resort of Tihany, he thought it "still preserve[d] some of its upper bourgeois atmosphere". The intense, purposeful flow of motorized traffic to Lake Balaton evoked the "decadent" pursuits of people in the free world.

The Wall Street Journal reported on manifestations of a "bourgeois lifestyle" in Romania, where communists "could enjoy the merry-go-round of night clubbing, sailing and opera recitals". Later, the New York Times would celebrate changes in Romania in a small press campaign. The US Legation in Budapest reported in 1961 that the number of American visitors to Hungary had grown significantly, and that many were surprised by the courteous treatment they received from Hungarian authorities. A Christian Science Monitor correspondent was pleasantly surprised by the significant changes that had taken place in Hungary since 1956, but an American conductor of Hungarian descent, László Halász, found a different reality in 1962. Halász had once thought that changes for the better had occurred in Hungary, but two visits convinced him he had been mistaken. "There is general fear, cultural stagnation and except in showcase 
Budapest, a serious food shortage." ${ }^{34}$ Dissent notwithstanding, a narrative was being constructed to improve the image of satellites in hopes of earning them better treatment by the US. They were no longer depicted as mortal dangers to American values, but as places that were assuming more human qualities. The psychological barriers to accepting the communist regimes, and that Soviet control of Eastern Europe was a more or less permanent phenomenon, were falling.

Czechoslovakia was a favored spot in the 1960s. Many Americans found reality there far more pleasant than the nightmarish image presented by anticommunists. Journalists found it to be a prosperous country even by Western standards, the only country where "Marx was right", although some remarked that Prague was just a showcase that hid a less happy truth. Even so, Czechoslovakia was considered the most flourishing state behind the iron curtain. ${ }^{35}$ Prague had begun to open up in the mid-'50s; Czechoslovakia's renowned spas in Karlovy Vary and Marianske Lazne were reopened in 1955. Six thousand Americans visited the country in 1958, and the motivation for allowing them to do so was twofold: an urgent need to earn hard currency and a desire to display the "human face" of socialism. ${ }^{36}$ Hungary also seemed to be on its way to more prosperity. In the view of the American legation in 1960, Kádár had "every reason" to be satisfied with the performance of his economy. In spite of a claim in New York Times - which would later champion the cause of "goulash communism" - there was no shortage of food in Budapest. ${ }^{37}$ And despite its political pronouncements, the Hungarian government was making cautious overtures to the West. There was interest in increasing the number of visitors. American Express included Hungary in one of its package tours: three nights in Budapest's art nouveau Hotel Gellért, or at the Royal, complete with sightseeing, wine-tasting and a night at the Opera. ${ }^{38}$ Such images evoked not communist drudgery but a more upscale and colorful middle-class existence.

Hollywood was making a comeback behind the Iron Curtain, as well, though not to the same extent in every country. In 1961, two American movies were among the most popular motion pictures in Hungary. Cinderella averaged 339 moviegoers at 3800 (!) screenings, while Around the World in Eighty Days was enjoyed by an average of 555 viewers per show. These numbers exceeded by a large margin the averages for Hungarian (206) and Soviet (174) films. Hollywood was equally popular in neighboring Czechoslovakia, where authorities considered cinema a potential tool for political subversion and cultural penetration. The first American film to be shown in Czechoslovakia in the communist period was screened only in 1960, and US movies would seldom appear there after that, although some were allowed into the Karlovy Vary film festival to raise its international prestige. ${ }^{39}$ Thus in this regard, Hungarian practices were more 
liberal. In his study of "soft power", Joseph Nye has pointed out that while American films may make the US look attractive in some countries, they may have the opposite effect elsewhere. Hollywood images could also attract one segment of the population while repelling others. ${ }^{40}$ Thus showing American movies behind the Iron Curtain was a double-edged sword. Some carried messages critical of the United States and underscored communist propaganda. So, on the basis of a "gentleman's agreement", an expert on motion pictures and propaganda in the US Legation in Budapest, Turner Shelton, "censored" whatever products the US movie industry intended to show behind the Iron Curtain. Disney went so far as to negotiate with the Hungarian state film company Hungarofilm to produce a movie in Hungary for distribution in the US. The State Department disapproved, fearing unwanted publicity for Hungary. ${ }^{41}$

Washington imagined Eastern Europe as a pro-American region. This was a dubious assessment, though, as there were no public opinion surveys to prove or disprove the assertion. Other evidence was circumstantial and sometimes hard to interpret. An attraction to American-made automobiles, for instance, does not automatically signify approval of US foreign policy. State Department assessments concluded that "the US in Eastern Europe can draw upon considerable assets of goodwill ... This fund of resources is perhaps unique throughout the region and unmatched by any Western country." America "has the most prestige of any Western nation in Eastern Europe", and therefore the American presence there had to be increased. ${ }^{42}$ Hungarians had considered mostly pro-American ever since World War II. Lacking reliable statistics, surveyors depended on metacommunication and signs to measure American popularity, such as the reactions of people on the street to an automobile flying a star-spangled banner.

In 1961, the chargé in Budapest perceived a drop in American popularity. He noted that he never saw any signs of hostile sentiment; in fact, people were ready to show their interest and friendship in many ways, including semi-hidden smiles, waves, hearty welcomes, and even gestures of agitation. He attributed the decreasing frequency of such friendly signs to the Berlin crisis and to Titov's space flight, which had showed that Soviet successes were real. This slide in popularity was also a part of a healthy maturing process, as the image of America as a romantic "white knight" shrank back to reality. ${ }^{43}$ In spite of the tensions, the US Legation sought to maintain contact with the Hungarian intelligentsia. This was not easy. Some, like the celebrated actress Éva Ruttkay and her spouse, for instance, rejected an invitation to a party organized by a foreign national and claimed that attendance "would not be wise". Still, the influential poet and translator István Vas did show up, and asserted that "the most exciting and most productive contemporary theater existed in the United States". The remarks of another poet of national recognition, Ágnes Nemes Nagy, were more characteris- 
tic of the paucity of knowledge about American culture in Budapest. Nemes Nagy had no idea that Ezra Pound had been born American, had never heard of Robert Frost, and declared that "only the British produce good poetry in the English language". 44

\section{Amnesty under US Pressure}

While tensions between the two superpowers were receding, the United Nations became the scene of a dramatic confrontation between the Western bloc and the East over censuring the Soviets and their now staunch allies in the Hungarian government. This would be American diplomats' first real success behind the Iron Curtain and would demonstrate the usefulness of diplomacy and the strength of the United Nations in exerting pressure on tyrannical governments. While international interest in Hungary was waning, there was not a single outstanding issue between Hungary and the US that was resolved. As long as there was no improvement, the United States would not be able to exert any influence, thus American diplomats in Budapest recommended a favorable response to Hungary's overtures on trade expansion and a readiness to drop the Hungarian question at the UN. ${ }^{45}$ While the diplomatic mission was closer to the real world in its day-to-day dealings with the communist government and often closer to the truth in arguments with the State Department, this time Washington's harsher approach turned out to be more productive. There was an impasse: the Hungarians were waiting for an American initiative in a diplomatic game of patience. Only Zádor, the Hungarian minister, took the initiative to find out the Americans' conditions for reconciliation. He told the State Department that while Hungary stood ready for talks, the government would not even consider any negotiations directed towards "changing Hungary's social order or provid[ing] unilateral advantage to the opposing political forces in the current international situation". "In response, Livingstone Merchant, the head of the State Department's Office of East European Affairs, confided that what mattered for Washington was not the domestic order of an individual country, but its relationship to the Soviet Union. Ceaussescu's Romania would go on to become the best example of this initially rather rigid, but later more flexibly interpreted formula. In Hungary, there was no apparent sign of autonomy from Moscow or even a domestic ideological thaw. International relations were still seen through the prism of Marxist ideology as a struggle between the "forces of progress" and imperialism. The Hungarians' "main question" was whether the expansion of American imperialism could be halted. ${ }^{47}$

Referring to the spirit of Camp David and the imperative of reducing international tensions, Soviet Deputy Foreign Minister Vasili Kuznetsov tried to convince the $14^{\text {th }}$ Assembly of the UN to drop the Hungarian question for good, but to 
no avail. At Cabot Lodge's initiative, the world organization once again condemned the Soviet Union and the Hungarian regime for failing to implement UN resolutions in Hungary. ${ }^{48}$ Budapest was thus forced to revert to diplomacy and the politics of "small steps", moving from easily resolved problems to more difficult ones. ${ }^{49}$ They began negotiating economic issues such as animal health, hoping to be allowed to sell meat in the US for the first time since the war. ${ }^{50}$ Their main purpose was the "liquidation" of the Hungarian question. ${ }^{51}$ Hungarian leaders were willing to make an offer on Mindszenty, but affirmed that no "compromise of principle" would be made, and required that any formula take into account the "prestige and sovereignty" of the Hungarian People's Republic, a condition they would take very seriously.

Budapest wanted to be viewed as an independent entity on the international scene. The Political Committee, the country's highest decision-making organ, concluded that an offer for "normalization" should be made if the four-power summit scheduled for May 1960 were successful. This initiative included an offer to resolve the Mindszenty problem. ${ }^{52}$ The conditions set by the Politburo were wholly unrealistic, betraying an ignorance of the possibilities for Hungarian (and even Soviet) foreign policy. Up to that point, the Party had regarded an exchange of ministers as the precondition of normalization talks; now it was meant to be a "reward" for the Americans if they would stop "spying", cease giving refuge to the Cardinal, and terminate their economic embargo against the socialist bloc. It was as though the Political Committee did not take its own initiative seriously. The best solution for the Hungarians would have been house arrest for Mindszenty, with the Catholic Primate's release from the country dependent on "international conditions". ${ }^{53}$ That meant the US would have had to guarantee that the cardinal would not publicize his political views, a condition that was not unacceptable to the US.

The Hungarians seemed to forget that any solution would require the approval of the Vatican and the cardinal himself. Budapest insisted that the Vatican remove Mindszenty from his position as head of the Hungarian Catholic Church, thus the affair grew into a quadratic equation the chief variable of which was an obstinate individual who had made it his personal mission to combat communism. ${ }^{54}$ In the meantime, the Political Committee hoped that the US would take the first step. The Hungarian Foreign Ministry may have had a small degree of independence from the country's leadership: the minister in Washington seems to have acted independently in using a Swiss mediator to inform the State Department that the government in Budapest was willing to take into account whatever recommendations the US administration might make, or to make specific recommendations of its own if it would contribute to a normalization of relations. The mediator, Joseph Milleger, added that he and Zádor had discussed the possibility of releasing Mindszenty to Switzerland. He also claimed that the Hungarian foreign minister 
was ready to approach the US minister in Budapest to discuss the Mindszenty question, which was then considered the main impediment to a restoration of relations. The State Department refused the Swiss mediator's services, questioning his authenticity, and affirmed that they would keep the Hungarian question on the UN agenda in order to preserve the prestige of the UN and remind the "free world" of the Soviet Union's behavior in world politics. ${ }^{55}$ Hungarian records contain no trace of this strange episode, thus it is hard to say what may have motivated it. Given that it was the most sensitive issue in contemporary Hungarian international relations, it could hardly have been the initiative of a single diplomat. Perhaps it was a trial balloon meant to sound out the State Department. This would indicate that an agreement was more important to Hungary's leaders than the transcripts of the Political Committee's meetings suggest.

The whole thing came to naught as an ill-timed U2 spy mission wrecked the 1960 summit. ${ }^{56}$ Thus, seemingly because of world politics, but more probably because neither side was ready for substantial compromise, the Hungarians dropped their grander schemes for normalization. The Foreign Ministry pointed out that Soviet-American relations had deteriorated and that the US administration was not in a position to relax economic controls without congressional approval. ${ }^{57}$ In 1961, Kádár went to the UN, setting foot in the US for the first - and last - time in his life. On the way there, he enjoyed Khruschev's company on the oceanliner Baltica, playing cards and his favorite game, chess. In New York, he asserted that Hungary was ready to discuss normalization, but he also attached a warning: "if possible we would like to avoid severing diplomatic relations with your country". ${ }^{58}$ The American minister in Budapest commented that relations between his government and Kádár's "turncoat" regime had never shown any real signs of change. The State Department's short-term goal in 1961 was to encourage peaceful progress toward a larger measure of national independence and internal freedom for Hungary. Full independence and the free choice of government would remain aims to be achieved in the future; but as was noted then, almost no progress had been made since 1956. US officials believed that communist rule in Hungary rested on Soviet power, police terror, and the suppression of civil rights, but given the tensions between the two countries, American goals had to be modest. They would begin by letting go of the Hungarian Question and restoring the legation's ability to function, thus increasing American influence. ${ }^{59}$ It was added that though the Hungarian Question was already losing currency, the worst was still to come. Despite the standoff, it was thought that the "average non-official Hungarian" still respected the United States. ${ }^{60}$

As the memory of 1956 faded, the Kennedy administration grew eager to “engage" Eastern Europe. The State Department was anxious to get over 1956, 
instructing the US ambassador to the UN to drop the Hungarian Question as soon as possible so that the US could make contact with the "Hungarian people". 61 This coincided with a new Hungarian initiative: Foreign Minister Sík, probably inspired by the forthcoming meetings between Kennedy and Khrushchev, wished to make a "significant" overture to the Americans. He considered eliminating travel restrictions, but since this was a security issue, he would need the consent of the Ministry of the Interior. ${ }^{62}$ In the meantime, the head of the State Department's Office of Eastern European Affairs declared that the US would regard it very favorably if the travel restrictions imposed on US official personnel were lifted, and suggested such a move would be reciprocated. This, however, would not involve the UN. ${ }^{63}$ Sík's measure was rather radical by Eastern European standards; similar restrictions applied to Americans all over the Soviet bloc. As with any decision made by the Political Committee, the Soviet ambassador, Dmitrii Ustinov, was consulted. He gave his blessing to Sík's initiative, as did Hungarian Minister of the Interior Biszku, and thus the diplomatic note announcing the removal of travel restrictions was handed to the US legation. ${ }^{64}$ Although this move was not insignificant, it paled in comparison with the freedoms Romania was seeking at that time. Gheorghiu-Dej had threatened Moscow that Romania would leave the Comecon, and Khrushchev had rescinded his plan for Comecon unification rather than work at cross purposes with Romania's economic policy. ${ }^{65}$

If the Hungarians thought that they could offer Mindszenty in exchange for a UN mandate, they were in for a disappointment. On April $5^{\text {th }}$, 1961, the State Department official in charge of Eastern Europe, Harold Vedeler, told Zádor that there would be no normal relations until the Hungarian Question had reached a "satisfactory" resolution. ${ }^{66}$ Given the ongoing reprisals in Hungary, this was of crucial importance, both to the Hungarians and for America's prestige as the champion of victims of communism. By then, the affair had become a battle of nerves. The President of the UN General Assembly, Frederick Boland, thought that the US should refrain from raising the issue because the "Asian-African" group that usually supported Western initiatives considered Hungary a "Cold War" matter. ${ }^{67}$ The Soviets were throwing everything they had at jeopardizing the work of the UN's Special Committee on Hungary. Witnesses were intimidated and the spiritus rector behind the investigation, the Danish diplomat Bang Jensen, was found dead in Central Park. It was suspected that he was murdered by the KGB.

The US ambassador to the UN, Adlai Stevenson, thought that the Hungarians might have been ready for a troop withdrawal - Kádár had referred to it in a speech - or for a political amnesty, but that it would not recognize UN authority. On August $3^{\text {rd }}$, Deputy Assistant Secretary of State Richard H. Davis read a note to the interim Hungarian chargé, Károly Hackler, in which he expressed his 
"wish" that Hungary would release all political prisoners as part of a general amnesty during Boland's planned trip to Hungary. Davis intimated that a positive response would result in the Americans' dropping the Hungarian Question. ${ }^{68}$ Secretary of State Dean Rusk wanted the Hungarians to know that they would be expected to take drastic measures to improve their situation and resolve the Hungarian Question. Amnesty for those imprisoned for their roles in 1956 would contribute significantly. ${ }^{69}$ They worded their note in a way that did not suggest a setting of conditions, but rather "sincere realistic proposals". If Boland's trip were successful, Washington would drop the Hungarian Question, accept the mandate, and begin bilateral talks. ${ }^{70}$ This time, it was the Americans who were mistaken in thinking that the Hungarian government's dire predicament would induce it to seize opportunity to get out of its strangling international isolation.

In his report to the Foreign Ministry, Hackler qualified the American proposal as an effort to interference. He reported the precise conditions without mentioning the wording of the "sincere proposal". Then a Hungarian News Agency reporter, Dénes Polgár, told an American journalist of Hungarian descent, André Marton, that the "opportunistic and incompetent" Hackler would not faithfully report what the Americans said and that Budapest would be able to cite interference in its domestic affairs. Marton reported these comments to the State Department, ${ }^{71}$ and the following day US chargé Torbert repeated Rusk's message to Sík. Regarding a Soviet troop withdrawal, Sík referred to the Warsaw Pact and claimed that the party leader would construe any proposal for amnesty as an attempt to interfere in Hungary's affairs. ${ }^{72}$ Boland's visit was called off. The Hungarians claimed that it was because the Americans had made "unacceptable demands" concerning eventual Soviet troop withdrawal, liberalization of Hungarian travel abroad, and amnesty for 1956-ers. ${ }^{73}$

Developments in world politics did not help. The standoff in Berlin and the subsequent construction of the Berlin wall, along with Kennedy's fiasco at the Bay of Pigs, sharpened tensions between the two blocs. Washington put the Hungarians on the spot with renewed energy, using it as a proxy to put pressure on Moscow. When János Radványi, a former officer of the Hungarian political police and the new Hungarian chargé, tried to convince Presidential Advisor Chester Bowles that the general amnesty was Hungary's own business, he was told that "1956 was not an internal problem". ${ }^{74}$ Assistant Secretary of State George Ball called the Hungarian problem a "special affair" that involved the "basic principles of the UN" and warned that it would return to its place on the UN agenda. ${ }^{75}$ Rusk again affirmed that there would be no normalization of relations between the US and Hungary without a satisfactory resolution of the Hungarian Question, which above all meant amnesty for the 1956-ers. Only then would the US begin talks about an exchange of ministers or the eventual elevation of diplomatic representation to the embassy level. ${ }^{76}$ And still there was no sign of an accord. 
Deputy Foreign Minister Szarka complained of US intervention and efforts to overthrow his government. When János Péter, an ordained bishop of the Reformed Church, replaced Sík as the new foreign minister, the US Legation in Budapest noted that this did nothing to help relations between the two countries. ${ }^{77}$ At that point, however, Kádár signaled that his country was interested in making progress. He declared that Hungary's desire to settle bilateral relations was motivated by the hope that it could catch up with the West.

At one diplomatic reception, Kádár approached an American diplomat for the first time in his life. In this, as in many other respects, he would go through a remarkable change. After showing genuine hostility to the United States, seemingly in the Leninist belief that it represented the highest and most dangerous phase of capitalist development - imperialism - by the middle of the 1970s, he was eager to visit it. For now, he would strike a conciliatory note, explaining that conflicts in the world were between states, not people. He preferred not to use the word "enemy", generally referring to the US as an "opponent". To ease tensions, he would joke that from a certain perspective he would not like to dissuade the Americans from their armament programs because if they were to devote their strength solely to economic expansion, Hungary would find it even harder to catch up. His aims, the party leader explained, were to overcome the inflexibility of his political system and to reach parity with Austria - a somewhat more realistic objective than Khrushchev's plan to overtake the US. He also explained his rationale for peaceful coexistence: though he complained that the US would overthrow his system in thirty minutes if it could, he admitted he would do the same to America's. It had to be recognized that neither eventuality was on the horizon. Torbert interjected that the US had different notions of building interstate relations. Americans were interested in the independence and prosperity of others; poverty and misery anywhere were a disadvantage to all. Kádár revealed his motives in replying that the poor were a problem, a reason progress needed to be made in Hungarian-US relations. They parted with an almost cordial handshake. ${ }^{78}$ Kádár appeared cold and reticent, convinced that he occupied a top spot on the list of America's enemies, ${ }^{79}$ but Hungary's Achilles heel had been revealed: its economy.

The Revolution of 1956 had emerged as a symbol of the struggle for freedom and against oppression. As the State Department's communiqué on the fifth anniversary put it, Hungarian patriots had fought courageously against uneven odds for their freedom and independence, and the free world would not forget their sacrifices. The communiqué emphasized virtues like self-sacrifice and courage, and ideals like freedom and independence. To help promote its own internal cohesion, 1956 was portrayed as a struggle to be emulated by Americans; however, the president and the vice president both rejected invitations to an event organized by the Hungarian Freedom Fighters' Association to commemorate the 
uprising. ${ }^{80}$ There was no need to irk the Soviets, and revolution had since been replaced by evolution as the ideal method for transforming Eastern Europe.

Kádár's conversation with Torbert occasioned a shift in the attitudes of Hungarian functionaries, many of whom were accustomed to changing their masks as situations or party interests demanded. Szarka was behaving congenially and broached the opening of a commercial office in New York. Although the legation in Budapest would not reject the idea altogether, the State Department would have none of it. Assistant Secretary of State Chester Bowles instructed Budapest not to enter into any "initiative" with the Hungarians, however minor. He would allow them to discuss proposals to abolish the staff cap, travel restrictions, family unification, and work permits for the legation's Hungarian employees $^{81}$ - all of which fell under the jurisdiction of the Interior Ministry. Szarka also mentioned the negotiation of a cultural agreement, something that the US and Romania were already discussing. Later, Washington would exert considerable pressure to conclude such an agreement, but at this point the State Department would reject Szarka's offer. They claimed that the US did not usually sign formal cultural agreements with foreign states and would negotiate cultural exchanges only after relations were normalized. ${ }^{82}$ Peaceful engagement did not yet include Hungary; the old policy of quarantine still seemed the preferable option.

The legation in Budapest tried to get things moving by suggesting that the regime was attempting to forge a better international image of itself and improve relations, even if it was not yet ready to pay the price. Domestically, the regime's record was mixed. The regime was seen to be countering popular anti-Soviet and anticommunist hostilities with a campaign against contrarianism, indifference and apathy. At the same time, an anti-leftist trend and even an anti-Catholic campaign seemed to have appeared in the party hierarchy. The government had consolidated its stability and self-confidence, and though physical and psychological inculcation had not increased loyalties in the army, resistance to the regime was weak and sporadic. ${ }^{83}$

As a small sign of opening to the West, the Foreign Ministry appointed a new desk officer responsible for the US, who was thought to be more knowledgable and urbane, as well as intellectually faster than his predecessor. János Bartha also had personal experience of the US and spoke better English, which created expectations that he would improve the dialogue with the US. The appointment of a new chargé d'affaires to Washington was also interpreted as a sign of progress. János Radványi had served as the chief of the protocol section of the Foreign Ministry and was thought to be enthusiastic and discreet. The legation in Budapest understood that Radványi regarded his mission as a great personal opportunity and entertained certain illusions about what he would be able to achieve. ${ }^{84}$ Later, Radványi sought to discredit his predecessor as a hardliner, although he was told 
by State Department officials that despite the tensions between the two countries, Zádor had shown a correct and friendly attitude. ${ }^{85}$ Radványi would eventually create a scandal by becoming the first Iron-Curtain ambassador to defect, and would then make a scholarly impact in debunking disingenuous Hungarian efforts to mediate in the Vietnam War. However, the US foreign service did not know about a dark chapter in the diplomat's career, namely Radványi's service as an officer in the feared Hungarian secret police, the ÁVH. The experience with Radványi underlines the fact that the true identities of emissaries from dictatorships are unknowable.

Even before the new chargé's arrival, the State Department made known that a favorable resolution of the Hungarian question at the UN could be expected only if domestic changes were to convince lawmakers and the US public that such a concession could be justified. As an "effective argument", the State Department proposed an announcement that there was no one still in prison as a result of the 1956 revolution. ${ }^{86}$ Since a partial amnesty had already been announced in 1960 , this was not an impossible condition. There is no doubt that this condition, which was later called a "recommendation", would have infringed on Hungarian sovereignty if the country had been a sovereign state, but that was not the case. At the UN, Deputy Foreign Minister Péter Mód accused Washington of linking normalization with amnesty. The State Department claimed that Hackler misunderstood what he was told: amnesty was not meant to be a precondition; that would have amounted to interference in Hungary's domestic affairs. In an effort to find an acceptable wording, Turner Shelton indicated that some kind of a theatrical gesture would be required lest he dare utter the word amnesty. Radványi, who allegedly received personal instructions from Kádár to repair US-Hungarian relations, ${ }^{87}$ thought that this formulation was acceptable and told Turner that his government would consider any serious advice ${ }^{88}$ However, the Ministry of Foreign Affairs rejected Turner's formula. ${ }^{89}$ As a result, Radványi backpedalled and adopted a hardline stance. He sought Foreign Minister Péter's "professional advice" in interpreting communications with the Americans. On April $26^{\text {th }}, 1962$, he asked the State Department for new "suggestions" on ways to jumpstart bilateral relations, as this was his mission in Washington. He was told that the Hungarian government would be expected to make a gesture clearly demonstrating that the events of 1956 were permanently closed. It was added that amnesty for the participants of the uprising was not a precondition, merely a suggestion. ${ }^{90}$ Radványi reported this exchange to his superiors in Budapest, and to avoid any misunderstandings, he left the word suggestion in the original English. Still smarting from the upbraiding he had received from the foreign minister, he reversed his earlier stance and said that there was nothing new in the American formula, which "amounted to an intervention in our domestic affairs". 
Radványi also volunteered his own appraisal of American politics. In the 1950s, Hungarians could not report on the US without including an expression of moral outrage, and Radványi now took up this tradition in asserting that Washington was a "captive of its own propaganda". "They permeate their own public through and through with the poison of hatred and lies" and were hence "unable to break out of the circle they created even out of self-interest". At the same time, he warned Budapest that the administration would not pick a fight with Congress or with public opinion, and thus it could be years before the Hungarian Question could be settled. He opined that even "within the Kennedy administration's subversive activities an American effort towards normalization can be discerned". 91 The Hungarians were still waiting to make a move, ${ }^{92}$ so the State Department took the initiative. In a conversation with Dénes Polgár, a journalist with connections to the state-security services, Vedeler reiterated that American diplomats had no desire to set conditions, but also stressed that only an amnesty would reassure Congress and the public. If the government decided to exculpate participants in the events of 1956 at its own initiative, the Hungarian question would be resolved and concerns like trade, cultural relations, and Mindszenty could be addressed to their "mutual satisfaction". Vedeler warned that normalization talks would begin only if the Hungarian question was settled at the initiative of the US, not if it sank into oblivion, or in any other way. The next step would have to be made by the Hungarians. ${ }^{93}$

A few days later, in what the US chargé described as a generously executed gesture, Kádár indicated that he was ready to make progress, though he failed to mention any concrete steps. The Foreign Ministry signaled that Hungary would be ready to explore any domestic measures that might improve the country's position at the UN and thereby satisfy American conditions for improved relations. It was also added that "psychologically Hungary could not afford to sacrifice its pride and self-esteem by [giving] in to pressure". Zádor added that the Americans were mistaken if they thought that the Soviets were still exerting a "decisive influence on the politics of its allies". ${ }^{94}$ Hence, he suggested, the decision on amnesty was in Hungarian hands. In contrast, Torbert thought that Hungarian independence from the Soviets was nominal at best. In an astute appraisal of the many sources of Hungarian conduct, he argued that Kádár's freedom of action was insignificant given Hungarian nationalism, Stalinism, Soviet interests, the pragmatism of progress, internal liberalization, and the memory of the role the liberal intelligentsia had played in the 1956 rebellion. Kádár was a successful tightrope walker: he made cosmetic changes, but held himself firmly in place. ${ }^{95}$

Budapest was eager to offer Mindszenty as part of the price of a general settlement, but this intention did not mesh with the Cardinal's wishes. When the Hungarian deputy prime minister, Gyula Kállai, announced at a press conference that his government was ready to discuss the archbishop's future, Mindszenty sent a 
message to Secretary of State Dean Rusk asking him to forward a letter to the Holy See in which Mindszenty expressed his desire to stay at the legation, even if he were allowed resume his ecclesiastical functions. His position was shared by the papal nuncio in Washington, who had been assured that Mindszenty could stay in the American mission since there was no realistic chance of an agreement. ${ }^{96}$ The Holy See agreed on the grounds that Mindszenty was the Hungarian nation's spiritual leader. His presence in Hungary was desirable; his departure could have a depressive effect on the people. ${ }^{97}$ In spite of all this, the Vatican was not looking for a way out and did not oppose the Cardinal's departure. In fact, the papal state requested Hungarian government permission for Mindszenty to attend the Holy Synod in October 1962, where it hoped he would stay and allow himself to be sidelined. The US also made overtures in support of this solution. ${ }^{98}$ Budapest concluded from all this that the Americans were trying to rid themselves of the affair, and thus that the Hungarians were winning the diplomatic game that had been dragging on for years. The Political Committee's appraisal was that the Americans were trying to dump the cardinal, and that their demands were therefore diminishing. Thus the "package" they put together was utter disconnected from reality. It included a new condition for the Catholic Primate's departure: the return of the Crown of Saint Stephen. This "political concession for normalization" would further require that Mindszenty stay in the Vatican and be stripped of his ecclesiastical functions. Communist leaders thought they might even be doing the Americans a favor, since the US "would be able to get rid of both Mindszenty and the Hungarian Question". The Hungarian Question was important from many perspectives: beside its "domestic significance", it could have a "demoralizing effect on the hostile circles of the Hungarian emigration", and was also "significant from the perspective of the Soviet government".

In addition to a compromise on Mindszenty, the Political Committee was also ready for a settlement "of the matters relating to 1956 [for the] foreseeable future". Their price, however, would be unrealistic: the resolution of the Hungarian question, an exchange of ministers, and the return of the Crown. ${ }^{99}$ It was true that Mindszenty's refuge was causing problems. A Swedish publisher somehow found out that the aged prelate was working on his memoirs and asked for them to be smuggled out to Stockholm in an American diplomatic pouch. The Americans rejected the idea, partly on the grounds that a diplomatic pouch could not be used for such purposes, and because the "unusual and sensitive" nature of Mindszenty's position would not allow him to use the building for ecclesiastical or political purposes. ${ }^{100}$ This does not mean that they were ready to throw him out. Torbert appreciated "this gentleman's freshness and spirit" and his interest in current affairs, even though he was obstinate and spent most of his time reminding people how far he was from being senile. After his inauguration, America's first Catholic president, John F. Kennedy, made a point of greeting Mindszenty, assur- 
ing him of his "full sympathy", and making known that the US government would grant him refuge as long as his personal security and freedom required it. ${ }^{101}$ Thus the Hungarians misread the situation. On October 9 1962, Radványi declared that Mindszenty would be released from Hungary if he were to plead for amnesty in advance. ${ }^{102}$ The Vatican simultaneously suggested that the Arcbishop of Vienna, Cardinal König, could pay Mindszenty a visit, but the State Department turned the offer down on the grounds that Mindszenty's predicament was too sensitive. ${ }^{103}$

In the meantime, the Hungarian chargé launched exploratory discussions after consulting with the Soviet ambassador, Anatolii Dobrynin. Relations between the Soviet Embassy and the East European diplomatic missions in Washington were close and extended to Soviet briefings on world affairs and intelligence activities. Dobrynin agreed with both "the principle and the implementation". ${ }^{104}$ Hungarian émigrés had already protested in the belief that the administration had decided to drop the Hungarian Question. The British also let it be known that they were eager to discard the whole affair. ${ }^{105}$ In September, Hungary proposed discussing the Mindszenty question in return for a preliminary American guarantee regarding the Hungarian Question and the amnesty, so as to avoid any semblance of domestic interference. ${ }^{106}$ Since it was becoming increasingly difficult to inscribe the issue on the UN agenda, Bruno Kreisky sought to convince Rusk that the Hungarians were more likely to take steps if there were no great external pressure on them. ${ }^{107}$ UN envoy Stevenson fretted over the possibility of a Soviet diplomatic victory and recommended other measures to avoid a loss of prestige. ${ }^{108}$

Radványi was told that if the Hungarian government were to carry out the amnesty as a public policy, the Americans' first step would be to take care of the Hungarian Question. As opposed to the Hungarian position, which tied the regulation of all outstanding issues to the amnesty, Radványi indicated that trade, cultural-exchange programs, and the exchange of chiefs of mission could be negotiated after the amnesty was declared. He made no mention of the Crown. Shortly thereafter, Deputy Assistant Secretary of State Davis presented a "written document" - emphatically not a diplomatic note - which spelled out the American terms. In order to avoid the charge of domestic interference, the word amnesty was replaced with formula expressing US hopes that the Hungarian government, at its own initiative, would publicly release any persons still imprisoned for their roles in the Revolution of 1956. If these hopes were satisfied, Washington would see to it that Sir Leslie Munro's Committee of Five, the group in charge of the Hungarian Question, were terminated; that no more resolutions critical of Hungary would be passed; and that Hungary's UN mandate would at last be recognized. The US would issue a declaration calling attention to the new circumstances in Hungary and would affirm that the Hungarian Question no longer served the cause of progress. Thereafter, negotiations would begin on the restoration of normal relations. 
These would include lifting the travel restrictions imposed on official personnel, as well as financial claims, family unification, cultural exchanges, and Mindszenty. Davis presented the text of the official declaration to Radványi for his personal use. At his government's instruction, the Hungarian chargé showed the document to Dobrinin, who voiced his "personal view" that if the Hungarians had already decided on certain domestic policies, the Soviet Union "can only concur". ${ }^{109}$ The whole issue was uncomfortable for Moscow and it is evident that Budapest was procrastinating rather than make a move against the wishes of the Soviet leadership.

In the meantime, the Cuban missile crisis erupted. US-Soviet relations had been troubled for some time, partly as a result of Khrushchev's brinksmanship. First, he had set out to alter the four-power status of West Berlin, threatening to sign a separate peace with the GDR if his demands were not met. Then, succumbing to pressure from East German leaders, he moved to construct the Berlin Wall, which would become the metaphor for Europe's Cold War division. He thereby stabilized the GDR - and the situation in Central Europe. ${ }^{110}$ But when the German crisis had subsided, Krushchev's efforts to alter the balance of power and preserve Fidel Castro's revolutionary regime led the Soviets to deploy nuclear missiles in Cuba, and it was only the political prudence of President Kennedy that saved the world from a nuclear catastrophe. The Cuban fiasco may have played an important role in Khrushchev's subsequent removal. Kádár later claimed at a meeting with Averell Harriman in Budapest that Khrushchev, with whom he was on excellent personal terms, had confided to him his plan to deploy missiles in Cuba. He claimed to have tried to dissuade Khrushchev from carrying out the scheme, but to no avail. It is hard to say whether his story was true or not. It definitely reveals that the Hungarian leader wanted to be seen as a realist who understood international power. Normally, the Soviet allies in Eastern Europe would not have been formally consulted or even told about Soviet intentions; most were given limited information about the missile crisis, and only after the US had broken the news.

This diplomatic tug-of-war around the general amnesty made clear that the satellite states could defy the power that controlled them in matters relating to a third power as long as that third power was an opponent of their hegemon. Even though Dobrinin gave Budapest a green light for putting an end to the reprisals and accepting Washington's conditions for a settlement, the Hungarians kept dragging their feet. Radványi advised the Foreign Ministry that the amnesty would be equal to surrendering all "our principles", though he was obviously saying what he expected his superiors wanted to hear. Then Khrushchev told his counterpart in Hungary that there was nothing wrong with accepting the American conditions. ${ }^{111}$ Shortly thereafter, the VIII ${ }^{\text {th }}$ Congress of the HSWP announced that 95 per cent of 
the people who had been "condemned for counter-revolutionary crimes" as a result of the events of 1956 had been released.

In late November, Harold Vedeler was negotiating with Foreign Ministry officials in Budapest when his hosts explained that it was hard for a small country like Hungary to be seen as bending to external pressure. Vedeler, who was satisfied with the Hungarian attitude, was reminded of Kádár's statement that the Presidential Council would review the cases of the last 5 percent who were still incarcerated. ${ }^{112}$ Deputy Foreign Minister Mód also hinted that his government was considering an amnesty, ${ }^{113}$ which was finally announced in April 1963. Washington was still dissatisfied with the steps the Hungarians took to implement Davis's conditions and chose to employ a new strategy. Washington announced the termination of Sir Leslie Munro's mission, which had been taking a lot of criticism. His assignment was taken over by the General Secretary of the UN, though the US continued to advocate the suspension of Hungary's mandate. This recommendation hardly made it through the relevant committee - the Greek representative disregarded the instructions of his government and voted against the Hungarian mandate. The Hungarian mandate was eventually accepted at a special session of the UN in May 1963. By then, the Hungarian Question was no longer on the agenda.

The Hungarian amnesty was the first American diplomatic success behind the Iron Curtain since the satellite regimes had established. The UN turned out to be an effective tool for putting strong pressure on Moscow and its client state, the bloody, tyrannical regime of János Kádár. As the Hungarian Foreign Minister would acknowledge, Hungary ended its campaign of reprisals as a result of American pressure. There were important lessons to be learned. The diplomacy of the client states was becoming more autonomous, making it possible to defy Moscow's will in questions of smaller importance. Hungarians did so, asserting what they perceived to be their sovereignty. US diplomacy was thus forced to reckon with national self-esteem, even though communists were not believed to have such feelings.

\section{Dilemmas of Bridge-Building}

American observers noticed that the communist regimes in East Europe were becoming increasingly autonomous. They were beginning to assert that their national interests were not always identical with those of the Soviets. Signs that they were heading toward more independence from Moscow made the European status quo acceptable to the United States, if not necessarily desirable. Some went as far as to argue that the Soviet occupation had produced an unprecedented stability in a former cockpit of continental hostilities. Soviet hegemony thus seemed preferable to an unchecked flow of unbridled nationalism. And while nationalism might 
have been part of the antidote to unrestricted Soviet control, it had to be handled with care.

The planned intensification of American trade and cultural contacts with Eastern Europe proved difficult to implement. In the Johnson years, it was propaganda rather than reality. As an exasperated Ceaușescu aptly put it, not a single pillar of the bridge had been put in place. American analysts and policy-makers could not agree whether to offer expanded cultural and commercial contacts as rewards for better behavior, or whether the establishment of trade and cultural exchanges would hasten a political liberalization. There were also security considerations. The battle lines in Eastern Europe were still drawn as if it were the 1950s. The State and Commerce Departments insisted on bridge-building as a way of transforming the lands behind the Iron Curtain and diminishing European tensions. Eastern Europe also offered new markets to the US economy. The Pentagon and the Joint Chiefs, however, were still concerned about possible American contributions to Soviet military might and did their utmost to impede the implementation of the administration's trade new doctrine. Although these dilemmas would remain unresolved, the socialist states' desire for American trade, loans, and technical know-how was increasing. However, due to a combination of interagency rivalries, Congressional resistance, domestic interest-group pressures, and sterile debate about the merits of interaction with the communist world, the United States missed a historical opportunity to transform the East European landscape and save it decades of further devastation under dysfunctional dictators.

On the other hand, dealing with economically backward dictatorships was not a simple matter. Anxious to preserve their power with minimal concessions, these regimes used the increasing American willingness to negotiate as a means of extracting favors. By and large, they remained ideologically hostile to the US, which they suspected of trying to subvert them. There was also the Kremlin to worry about, although the Soviets do not seem to have resented Eastern Europeans' closer ties with the Americans, as long as it suited their interests. Both sides wanted scientific and academic exchanges, but with opposite purposes. The Hungarian communist government wished to bolster itself by bringing modern technology and scientific skill back to Hungary from the US, while minimizing potentially subversive exchanges in the humanities. Washington, on the other hand, hoped to use precisely this sort of cultural exchange as an element in its policy of external transformation. Trade expansion was equally difficult. East Europeans were unable to pay for the US goods they hoped to purchase and had little with which to barter. Hungary hoped American credit would fund a modernization of its economy, allowing it to produce goods worthy of global marketing. The backwardness of the Hungarian economy made loans for badly needed machinery risky, and trade restrictions like Cocom made things even worse. Thus the policy of bridge-building was fraught with contradictions. 
The mood swings in Moscow over the Americans' intentions also had to be contended with. The Soviets were concerned about American intervention in various parts of the globe, but perhaps their greatest concern was a NATO proposal to pool nuclear weapons, which suggested to the Soviets that such devices would be shared with the Germans. "What if another Hitler arose?" Prime Minister Kosygin asked. ${ }^{114}$ Averting such scenarios was the primary focus of Soviet diplomacy. And insofar as the Vietnam conflict hampered Soviet-American relations, it in turn impeded Hungarian efforts to mend fences with Washington.

\section{Towards a Modus Vivendi}

A reorientation of US policy was necessitated by the fact that the French, the Germans, and the British were reappraising their relationships with the communist bloc and trying to make them more constructive. British military leaders had concluded that Soviet leaders were unlikely to risk the consequences of a third global

conflict. ${ }^{115}$ In question was the degree of independence with which the nations of Eastern Europe could conduct themselves. Security remained the chief concern and US officials continued to see Soviet hegemony in Eastern Europe as a potential threat. Eastern European "vulnerability" could still be exploited, bearing in mind the "realities of power", namely Soviet preponderance in the region. At the same time, Western influence behind the Iron Curtain needed to be increased, and not by circumventing the local communist regimes, but rather with their consent. In 1964, Secretary of State Dean Rusk argued for policies of peaceful engagement, particularly in the cases of Poland and Romania, and even for Hungary, which was commended for having moved toward a more liberal policy of "national reconciliation". President Johnson used the term "bridge-building" to signify commercial, intellectual, and humanitarian exchanges with Eastern Europe, including tourism. ${ }^{116}$ The earlier policy of "quarantining" Eastern Europe was labeled "passive, sterile, and defeatist". ${ }^{117}$ The State Department supported Johnson and encouraged an intensification of trade relations in the hope that Romania and Hungary would be willing to go as far as Poland.

The practical implementation of bridge-building would take a long time to catch up with the rhetoric. Romania began making strenuous efforts to purchase US equipment for its oil refineries and synthetic-rubber factories in the final year of the Kennedy administration, and though the project enjoyed the unqualified backing of the US ambassador in Bucharest and (apparently) the president, the purchase never went through. The Department of Commerce made it clear that there would be no rapid expansion of trade relations with Romania because of Cocom regulations and the fact that the American business community was not ready. Despite Congressional resistance, Kennedy permitted the sale of US wheat 
to Eastern Europe; however, the AFL-CIO was able to insert a proviso requiring that at least half the shipments sail under the US flag, effectively sabotaging Kennedy's concession. Congressional opposition was at least partly a response to pressure from East European immigrants, many of whom considered opening the American market to communists equivalent to a betrayal of the fatherland.

After his inauguration, Johnson decided that Romania would be the test case for the new approach to East European trade. Up to that point, only Yugoslavia and Poland had been allowed to sell to the US as most favored nations. The US Chamber of Commerce was eager to follow up on the Johnson administration's pledge to intensify American economic interaction with the Soviet bloc. East-West trade had been impeded by denials of MFN status, as well as the fact that the Export-Import Bank had refused to extend commodity credit to countries under communist leadership. US firms also faced difficulties in acquiring licenses to market their products behind the Iron Curtain. These procedures were relaxed only for Romania and Poland. Bucharest made a particular effort to get its purchases licensed; it managed to secure permits for eleven plants' worth of equipment out of the fifteen for which it applied.

The importance of breaking into the untapped East European market was underscored when Firestone announced the construction of a tire factory in Romania and its competitor, Goodyear, immediately launched a counter-campaign. The Johnson administration was divided on the issue. Secretary of State Dean Rusk and Defense Secretary Robert McNamara supported an unconditional intensification of trade relations in the belief that commerce was important enough to the communist regimes to force them into political concessions. Rusk and McNamara approved of the sale of any commodity without direct military significance. In contrast, the Departments of Commerce and Agriculture would restrict sales to items that could be "drunk or eaten", and only on a quid pro quo basis. ${ }^{118}$ In April 1965, the Miller committee, set up by the president to investigate the question of trade with the Soviet bloc, presented its findings. Its report stated that US trade policy should promote autonomy in Eastern Europe and that the Soviet bloc should adopt the trade practices of the rest of the world. The committee recommended relaxing US licensing procedures on a country-by-country basis and for the president to be vested with the authority to extend a country's MFN status for a limited period. However, because of the Vietnam war, the committee's recommendations were never implemented. Bridge-building remained an empty doctrine. As Romanian party leader Ceaușescu complained to Johnson, "not a single pillar" of this East-West bridge had been built. ${ }^{119}$

By 1964, the question was how far the United States wanted the satellites to go. That year, the CIA's Special National Intelligence Estimate asserted that Moscow and the client states had established a new and less rigid relationship. This was partly due to political changes and partly the result of the communist regimes' re- 
alization that they could devote more attention to their own national interests. ${ }^{120}$ This statement suggests a misunderstanding of communist ideology common in US appraisals. For most leaders of the communist persuasion, Soviet and national interests were two sides of the same coin, inseparable. The CIA also asserted that Eastern Europe was facing a significant transformation the central components of which would be internal liberalization and economic reform. These problems would be closely tied to the questions of autonomy and relations with the western world. It was assumed that the Soviet bloc would become more diverse and that some countries would move toward political liberalization and more efficient economic principles. Leaders would approach these issues from the perspectives of national interests and local political conditions. And if the satellites were more independent from Moscow and closer to the West, Soviet intervention was thought to be less likely, a possibility only if "vital Soviet interests" were threatened. US officials expected Moscow, absent challenges to its client-state arrangements or defections from the Warsaw Pact, would be willing to tolerate a variety of the political systems and possibly even consent to manifestations of increased autonomy in foreign affairs. ${ }^{121}$ Secretary of State Rusk instructed US missions in Eastern Europe to refrain from the use of the term "satellite" in diplomatic correspondence; in his view the term was no longer adequate to describe these countries' relations to the Soviet Union. ${ }^{122}$ Hence a new image of the Soviet zone was being constructed so as to fit the new administration's more activist doctrine. Yet this new image was also calibrated to accommodate the continued existence of an East-West divide.

Despite improvements, conditions behind the Iron Curtain were still far from perfect. Communist economies remained inefficient and therefore produced mass dissatisfaction, manifestations of which were expected. ${ }^{123}$ Declining living standards in Poland and Czechoslovakia led the State Department to predict that instability there would grow. On the other hand, Romania, which the New York Times had called the most dynamically growing communist economy, and Hungary, where Washington perceived continued improvement, seemed to be stable. The best response to the threat of instability due to sluggish growth was an intensification of economic relations. ${ }^{124}$ There were also security risks inherent in the Soviet-dominated area. The communist governments were involved in a subversive campaign to promote the world-wide victory of communism. Their activities included military and financial aid to the communists of the "free world", clandestine shipments of arms, and training subversives in guerrilla action, intelligence, propaganda, political oratory, and the indoctrination of youth. Czechoslovakia and the GDR were considered the most active in these areas, followed by Bulgaria. Poland, Romania, and Hungary seemed to limit their activities to intelligence, clandestine broadcasts, and student training, which was "modest" in comparison with the former countries. US intelligence assumed that Hungary was col- 
lecting information on missile-launching sites and that there was close cooperation between Soviet, Czechoslovakian, and Hungarian intelligence agents. ${ }^{125}$ This was still a traditional estimate in the sense that it appraised the Soviet bloc according to the threats it posed to the West.

American officials also took a new approach in appraising the dangers of increasing autonomy in Eastern Europe. This line of thought questioned the desirability of eliminating Soviet hegemony. The CIA's SNIE for 1964 assumed that hostilities between East European countries and between Eastern Europe and the Soviet Union would come to the fore again soon. Frictions between Hungary and Romania could already be detected. ${ }^{126}$ The Political Planning Council deemed the division of Europe unacceptable because it put the United States in greater danger of a nuclear war. Yet there were also dangers inherent in the restoration of independence: "Unbridled nationalism in Eastern Europe might lead to possible renewal of the patterns of conflict that made the area such a cockpit prior to pax communista. This potential is evident in complex of latent and potentially dangerous territorial and minority issues in the area." This suggested that American goals in the countries then under Soviet domination would have to be less ambitious: "Continuing development of Western unity in close association with the US to a further loosening (but not severing) of abnormally tight bonds between the USSR and Eastern Europe, reduction in divisions between East and West" [emphasis mine]. In this formulation, American goals fell significantly short of a restoration of European unity. The juxtaposition of Western unity with a recognition of the Soviets' role further amplified the message that Europe's division was no longer seen as unnatural. Thus "reassociation" would not mean "political union or military alliance". The policy of bridge-building would serve to increase US influence and diminish the unnaturally high level of Soviet influence, thus enhancing European security. ${ }^{127}$ At this stage, no unanimous opinion had crystallized around a long-term goal; statements to this effect were contradictory.

Publicly, Secretary of State Rusk defined the long-term American goal in Eastern Europe as "evolution" toward the reestablishment of "national independence". His immediate goals, though, were incremental: work toward independence, a diminution of the danger of war, and slowing the spread of communism. ${ }^{128}$ In contrast, a State Department memorandum prepared for the National Security Council would go all the way: "We seek in Eastern Europe the establishment of conditions under which the people of each country may determine its own society; and where each country may enjoy national independence, security and normal relationship [s] with all other countries. This will mean the final dismantling of the Iron Curtain and the free association of Eastern Europe and the West." Thus the reevaluation of American goals was still in a state of flux. The State Department's ambitious program would link the solution of the German question to the resolution of the status of Eastern Europe and work towards the construction of a "last- 
ing" relationship with the Soviet Union. It recommended practical steps to break out of the diplomatic deadlock, including the settlement of outstanding claims with Hungary and Czechoslovakia, compromises on consular issues, and the lifting of travel restrictions on diplomatic personnel. These latter two countries would also be singled out for bilateral talks modeled on negotiations then underway with Romania and the Soviet Union. The elimination of discriminatory tariffs was expected to shift the economic focus of Eastern Europe toward the West, thus reducing its dependence on the USSR. Intellectual bridges would be constructed through the dissemination of American scholarships, library collections, scientific publications, cultural bulletins and films. American officials would encourage English-language instruction and the establishment of Chairs of American studies. Poland, Czechoslovakia, Hungary, and Romania were identified as suitable countries for cultural exchanges because they acknowledged the importance of American scientific and technological aid for the development of their economies. One official recommended a public-relations drive to convince people in the Soviet bloc of America's peaceful intentions. This was especially important in light of ongoing NATO discussions of its plan to share nuclear arms with West Germany, ${ }^{129}$ an idea that Soviet propagandists exploited, describing it as malicious US support for German "revisionism".

Washington was struggling to maintain the cohesion of the West at a time when the Soviet threat seemed to be receding. In those circumstances, putting an end to Europe's division was no longer an unquestioned dogma of American foreign policy. In fact, this ideal was gradually being left behind. "Promotion of Western cohesion is the primary objective. [...] Ending the partition of Europe is not necessarily the same thing as achieving a stable European settlement. The end of division could come about through the fragmentation of both alliances, could contribute to new conflicts and tensions, the end result could be the restoration of a futile past, not shaping a constructive future." ${ }^{130}$ Washington's chief ally in NATO, Great Britain, was also reevaluating its stance toward the Soviet Union and its client states. In 1964, the British Foreign Office concluded that the communist regimes were relying less on terror and coercion and more on improvements in living conditions. For these trends to continue, East Europeans would need to modernize their economies with Western capital and technology. Britain could back reforms and détente by developing closer commercial, cultural, and scientific contacts. Any weakening of the Soviet hold over Eastern Europe would now come about through evolution rather than revolution. In the long run, trade and cultural exchanges would help East Europeans gain greater autonomy from the USSR. The British economy would also profit from this trade with the Soviet bloc. $^{131}$

Crucially, Hungarian émigré leaders supported the new American strategy. Former Prime Minister Ferenc Nagy and the former Speaker of Parliament Béla 
Varga, both influential in émigré circles, claimed that their former countrymen preferred a policy of peaceful liberalization to one of liberation. ${ }^{132}$ Their support mattered: the organization of East European émigrés, the Assembly of Captive Nations in Europe, had condemned the policy of bridge-building, branding trade with the communists "immoral" because it meant importing goods produced by "slave labor". ${ }^{133}$ Talks aimed at putting this new doctrine into practice occasionally degenerated into hostile exchanges. Americans and their communist counterparts were not always rowing in the same direction. One legacy of the 1950s was that Congress exerted a strong influence on policies towards Eastern Europe, often opposing ties with communist regimes or insisting on strict preconditions. Finally, there was no meeting of minds within the successive American administrations about the implementation of this new line. Hungary's case was special in the sense that there were numerous unsolved issues that did not burden relations with other communist states. Hungarian leaders were open to an expansion of ties, but set a hefty price in insisting on the return of Saint Stephen's Crown. Progress remained painfully slow, even though the situation in Hungary was improving and the regime had managed to stabilize itself. ${ }^{134}$

The CIA concluded that Kádár had consolidated his power over the party while "silently" pushing his country down a path of gradual change and pragmatic improvements in the political and economic climate. He even managed to turn Hungarian nationalism to his advantage and, at least according to CIA analysts, lost the stigma of a Soviet puppet. This relatively liberal line was expected to continue. ${ }^{135}$ In 1963, the US chargé in Budapest suggested that year had been the best for the average Hungarian since the communists had seized power. ${ }^{136}$ The historian János M. Rainer has observed that in Eastern Europe, connotations associated with the '60s "remain to this day decidedly positive". It tends to be remembered as a decade of thaw, of breathing more freely, of hopes and chances and greater liberties than the previous decade had afforded. Despite political constraints, even the decade's cultural revolution managed to creep behind the Iron Curtain. Campaigns of forced collectivization and industrialization, brutal reprisals and discrimination against "class enemies" and "remnants of the old ruling classes", and protracted attacks on political opposition, lasted until roughly 1963. But then, the profound economic reforms introduced from 1963-1967 led to a measure of intellectual and cultural openness. Discrimination against social groups allegedly hostile to socialism abated. Kádár was not a reformer by instinct. Caught between Moscow and his own population, he ushered in reforms. These brought modest prosperity, the beginnings of a new social stratification in a fragmented and leveled society, some freedom of artistic self-expression, and more openness toward the capitalist world than anywhere else in the Soviet bloc. The youth protested mainstream socialist norms of behavior and tuned in to RFE to follow American trends. Wearing outrageous clothing and hairstyles, they attended rock concerts 
where they tolerated cover versions of British and American originals. The fact that the police could bring these youths in for parading around in smuggled, illegally purchased apparel demonstrates the limits of Kádár's little freedoms. ${ }^{137}$

Now that the Hungarians' political amnesty had removed one of the chief hurdles to the normalization of their relations with the West, they introduced an economic reform. It was clear that these reforms could not work without "opening" to the West, thus their most important precondition was to bring ties with the US to a normal footing. Given the Johnson administration's decision to engage with the communist regimes, the stage seemed to be set for rapid progress toward the desired intensification of the American presence in Hungary. In February 1964, Budapest proposed bilateral talks for the mutually acceptable resolution of outstanding issues. ${ }^{138}$ As expected, the main goals were the settlement of economic disputes and the elimination of trade discrimination. The American legation supported the initiative, having heard rumors that Khrushchev was about to announce the withdrawal of Soviet troops. This hope, along with the positive outlook on Budapest's talks with the Vatican, gave rise to optimism that progress could be made with Washington. The legation proposed that the two parties focus on Mindszenty, financial claims, and lifting the Hungarians' restrictions on cultural activities and diplomatic personnel. American officials thought that the Hungarian government would try to link outstanding financial claims to the country's MFN status and would work for a cultural agreement in order to enhance Hungary's prestige. ${ }^{139}$ The Pentagon was optimistic that Soviet occupation forces would be pulled out because they thought - for reasons left unexplained - that the Red Army's position on the central front would be enhanced if the four divisions stationed in Hungary were pulled back to Soviet territory. ${ }^{140}$ It was also assumed that Romania's overtures to the US would constrain Budapest to accelerate its normalization process. ${ }^{141}$ None of these assumptions seem to have been correct.

National Security Advisor McGeorge Bundy recommended accepting the Hungarian offer on the grounds that an increased US presence in Budapest promised substantial advantages. Hungary had gone further than any other satellite in de-Stalinizing its communist system, and this trend was continuing. Bundy expected the American owners of nationalized property to be compensated, a consular agreement to be signed, family unifications to be allowed, and commercial and cultural ties to be broadened. ${ }^{142}$ In sum, talks would be opened because Hungary had declared an amnesty and the Kádár regime was thought to be pursuing policies of national appeasement, independence, and liberalization. ${ }^{143}$ 


\section{Bilateral Relations in the Mid-1960s}

Theoretically, the conditions were ripe for a rapprochement. Both sides were motivated, but their positions were still widely divergent. The Hungarians were willing to negotiate on Mindszenty and a consular agreement, but shunned a cultural accord. As with all deals, the devil was in the details. Budapest was ready to settle financial claims, but only after being granted MFN status, and had no desire to lift its restrictions on diplomatic personnel or its ban on US information activities. ${ }^{144}$ The settlement of financial claims proved to be another stumbling block. Washington insisted on payments as a condition of further progress. Hungary's trade balance with the US was negative, and included long- and short-term debt, compensation for nationalized property, the surplus-property loan, and compensation owed for American property damaged in the war. Hungary had only 6 million dollars' worth of property frozen in the US. Most of the Hungarian property, estimated at 100 million dollars, that had been taken into the American zone during World War II was thought to be impossible to collect. This included obligations to Jewish owners of valuables stolen from the "gold train", some of which ended up in the hands of American army personnel and some of which were auctioned off. ${ }^{145}$ The US pointed out that the settlement of these claims would help Hungary borrow on international financial markets, which was in fact Kádár's main motivation. ${ }^{146}$ Western loans were an indispensable ingredient in the country's modernization and reform program. There was no breakthrough, even though Hungarians understood that without normalizing relations with America, they would not get the loans they needed. A chief factor in stalling these negotiations may have been the Vietnam War, which froze relations for almost a decade.

Even though comprehensive talks started in Budapest in May 1964, no agreement was reached on any of the most problematic questions. Secretary of State Rusk offered to meet his counterpart, János Péter, to break the deadlock. The Political Committee authorized the foreign minister to tell Rusk that Mindszenty could be released and taken out of the country if his "silence" was guaranteed. On the other hand, the party leadership still insisted that the country's MFN status be the prerequisite for any settlement of financial claims. ${ }^{147}$ Rusk was not completely opposed to MFN status, but it soon turned out that the differences could not be bridged. ${ }^{148}$

Mindszenty was still intractable. Saddled with the cardinal's upkeep, Washington was ready to accept the condition of "silencing" him politically. The problem was the Budapest-Vatican-Mindszenty triangle. Agostini Casaroli, the Vatican's state secretary for foreign affairs, indicated that Mindszenty wanted to retain his title as the Archbishop of Esztergom, i.e., the head of the Catholic Church in Hungary, and acknowledged that it would be hard to keep Mindszenty from making statements related to the Cold War. Mindszenty himself was reluctant to give 
up his refuge. ${ }^{149}$ His personal beliefs had become intertwined with high politics. Mindszenty was convinced that his departure would constitute "negligence" toward the loyal priests he had appointed. ${ }^{150}$ The communist leadership, evidently for the sake of some positive publicity, wanted the cardinal to sue for clemency, for that clemency to be granted by the Presidential Council (the country's highest legislative organ), and for the settlement to be published in the Hungarian press as Kádár put it, "even on page 11 in the sports section". More importantly, they would not hear of Mindszenty's retaining his ecclesiastical functions, a condition that would freeze the situation for years to come. ${ }^{151}$

Soon, Mindszenty's tuberculosis recurred, lending urgency to his departure. In September 1965, Radványi met Raymond Lisle, the State Department official responsible for Eastern European Affairs, to discuss the matter. The Hungarian left with the impression that the Americans feared the cardinal might die on their premises and were therefore eager to rid themselves of the problem. He intimated to Lisle that Budapest expected Washington or the Vatican to come up with a solution. Later that month, the Vatican's state secretary responsible for Eastern Europe travelled to Budapest for talks with the State Ecclesiastical Office, the government organ that oversaw and controlled church affairs. Casaroli indicated that there was no hurry because Mindszenty's health was improving. Lisle told Radványi that the Cardinal would not leave the building, and it was his impression that Casaroli supported this position. Lisle also disclosed that the State Department was putting pressure on the Vatican to persuade Mindszenty to leave. ${ }^{152}$ Shortly thereafter, the apostolic delegate in Washington told Lisle that the Vatican was interested in the prelate's departure but could not guarantee his political silence, even though it would serve the Vatican's interests. While claiming that Mindszenty should not be allowed to set conditions, Lisle called his case a humanitarian matter. Lisle was aware that the staff of the Foreign Ministry might have been more enlightened and more interested in Western contacts than the State Ecclesiastical Office. He therefore wanted the Foreign Ministry to take over and deal with Casaroli. He also indicated that the US would not take the initiative, but would be willing to bring the parties together. Eventually Lisle was told that Casaroli would be received on a "cabinet minister's level", but by then it was too late: Mindszenty's recovery removed the urgency of the matter. ${ }^{153}$

Considering that Budapest wanted to resolve its political issues before settling financial claims - precisely the reverse of American hopes - no positive outcome was in sight. The Hungarians referred to the settlement of financial claims as a burden on the country even though, as in the Romanian and Polish settlements, only a small fraction of its outstanding debt was to be paid; it was obvious that the political will for such a step was missing. Washington would not make progress in other areas until there was a deal on financial claims, but the stakes for Hungary were far higher. The economy had been struggling with a balance-of-payments 
deficit for some time, and by 1964, the year when the US-Hungarian talks started, the proportion of short-term debt among Hungary's obligations was worse than it had been even in the 1930s. Half of the debt to the capitalist world was made up of loans that were due in less than three months. Thus from the mid-'60s, Hungarian leaders were forced to borrow medium-term loans in order to purchase capital goods from the West. The idea that the US could serve as a source of financing for investments was raised during the second and third five-year plans. American financial markets were appealing because they offered dollars at less expensive rates than the European markets. The option to issue bonds would not be available to the Hungarian government until it settled its financial claims with the US; membership in the World Bank and the IMF would also require American support. ${ }^{154}$ On paper, at least, an agreement was in the interests of both sides: Hungary was in the process of discarding its inhibitions and using "capitalist" resources to finance its economy, while Washington was interested in stabilizing Eastern Europe and exerting more influence there.

Talks were held up by unforeseen events like the illness of the leader of the US delegation and the accidental forwarding of the necessary documentation from Washington to Bucharest. Again, though, the escalating conflict in Vietnam destabilized the commercial pillar of the bridge the diplomats were building. Americans feared that commodities they sold to Eastern Europe might be forwarded to North Vietnam. In January 1966, President Johnson asked for congressional authorization to use his presidential powers to sign trade agreements with Eastern Europe in the name of bridge-building, but the bill did not make it through the legislature. Instead, the Fino amendment barred the Export-Import Bank from lending to countries that furnished economic or military aid to enemies of the United States, including the Soviet Union and every other communist country except Yugoslavia. ${ }^{155}$ For the time being, at least, Budapest would not be able to get what it wanted, and the idea of talks began to lose their significance, even to the Hungarians.

\section{Soft Power}

Penetration into Hungary was not an impossible task. The United States Information Agency felt that Hungary was fertile ground for American cultural initiatives. By the mid-1960s, Hungarian leaders were ready to loosen cultural controls in exchange for Western economic assistance. Their calculus was relatively simple. Political stabilization would require some degree of popular contentment, and this sense of satisfaction could be purchased with a hike in the standard of living. This, in turn, would require the inflow of Western capital, "capitalist" consumer goods, machinery, technology, and know-how. Thus, a normalization of relations with 
the US was indispensable, and if normalization were to require concessions such as allowing Radio Free Europe to be freely received, Hungary would be penetrated with American popular culture. This threatened the ideological integrity of the state, but because of the previously outlined political and economic pressures facing the regime, it was left with little choice. Washington realized that gradual cultural penetration might encourage a step-by-step liberalization, from domestic reforms to an eventual opening up to the outside world. ${ }^{156}$ There is no doubt that the members of the Political Committee also understood this dynamic.

Poland was the main target for American cultural initiatives. Positive developments in Poland led the USIA to an ambitious plan for a library and cultural center in Warsaw. In 1959, Poland signed an agreement for an academic exchange involving 1000 applicants, while Czechoslovakia sent 100 and Hungary only $19 .{ }^{157}$ Private foundations also helped build East-West contacts. The Ford Foundation cooperated with the State Department in establishing cultural ties with the countries of Eastern Europe, especially their intellectual elites. ${ }^{158}$ The Ford Foundation and the Kulturális Kapcsolatok Intézete (Institute of Cultural Relations), the agency responsible for external cultural contacts - also a clandestine subsidiary of the security apparatus - established an exchange program in 1964 whereby Hungarian artists, scholars, and scientists would be able to visit the United States.

The selection procedure for this program illustrates some of the complexities of creating ties with ideological regimes. The list of candidates was carefully selected and vetted on the basis of professional and "political" criteria, meaning that they were screened for reliability by the Institute of Cultural Relations and its close affiliates at the Ministry of Interior. The Ford Foundation was then allowed to invite a short list of 25 people, plus five "outstanding cultural and scientific personalities", on an annual basis. No more than half of those selected were to be representatives of the social sciences. In theory, at least, the Ford Foundation could also nominate its own candidates, but these nominees would not appear on the list of applicants without the prior approval of the Institute of Cultural Relations. Ford's short list was then forwarded to an organ called the Tudományos és Felsöoktatási Tanács (Council of Science and Higher Education), which vetted it from the perspective of the "interest of the people's economy". And this was only the beginning of the convoluted process. Once approved by the Council, the list was then sent to the Ministry of the Interior and the Scientific and Cultural Department of the Central Committee of the Hungarian Socialist Party for further winnowing. Finally, the presidium of the Institute of Cultural Relations, with the participation of deputy portfolio ministers and representatives of the party leadership, drew up a final list. It was only then that the Ford Foundation received the final list of candidates. ${ }^{159}$

Washington pushed hard to open American libraries in Iron-Curtain capitals and entertained high hopes for the transformative effects thereof. But these 
calculations disregarded the fact that Hungarian state-security agents (as well as those of other bloc countries) would monitor visitors to US libraries, registering each individual in a file at the Ministry of Interior. Visitors could then be blackmailed into rendering services for state security organs. There is no doubt that the Hungarian librarian of the USIA facility in Budapest was recruited by state-security agents. Even as late as 1981, freshmen majoring in English were warned that using the American library entailed personal risks.

The Hungarians did make a momentous concession soon after the Hungarian question was resolved: they stopped jamming Radio Free Europe. The regime ostensibly did so to induce the station to alter its radical stances, but the more fundamental cause was probably the expectation that it would lead to US concessions on trade issues. Accidents do play a role in shaping history, however. The party authorized a decision to stop jamming on a provisional basis, but in a fateful misunderstanding, the Foreign Ministry announced it as a permanent measure. Although the Politburo was furious, the decision could not be repealed without risking a loss of face, and was thus grudgingly left in place. The Political Committee also made a highly debated decision to allow the United States to participate in Budapest's 1965 International Trade Fair. This was an important breakthrough for American champions of external transformation, who sought to instill American values in the communist states and to effect the gradual democratization of closed political systems by sending goods and intellectual products behind the Iron Curtain. Participation in the Budapest International Fair was an important beachhead for this economic and cultural penetration. ${ }^{160}$

Budapest was not unaware of American successes in this field, and party leaders were alarmed by the popular appeal of US “propaganda". In 1965, the Political Committee devoted several sessions to the evergreen topic of imperialist subversion. Prime Minister Jenő Fock, a leading economic reformer, contradicted those who said "imperialist propaganda in Hungary is unable to undermine the masses' confidence in the socialist system and diminish the attraction of socialist ideas"; this was "not true, it is capable of doing so and is diminishing it". ${ }^{161}$ The party's leadership thought that the United States and the FRG were "trying to pit the socialist countries against the Soviet Union and each other, to subvert the socialist system, to nurture dissatisfaction towards the party and the government, ultimately against the social order and thus to prepare the restoration of capitalism in the socialist countries. They are trying to achieve all this with the wide[-]range use of foreign policy, economic[,] cultural[,] and personal contacts[,] as well as powerful anticommunist propaganda." They asserted that "subversive attempts mainly manifested themselves in the differentiated treatment of socialist countries", namely that some states got better treatment than others. Hostile intent was attributed to scientific and cultural contacts, which Party leaders warned would "open the door for bourgeois ideology and its products under the pretext of peace- 
ful coexistence". All this had alarming consequences for the future of socialism: "subversive propaganda plays a role in the sense that in the ranks of the public and particularly in certain circles of the youth and the intelligentsia there is an intensification of love of the West and of nationalism which is coupled with the downplaying of the results of socialism". ${ }^{162}$

What could be done in such a situation? Kádár was not in a position to go back to the isolation of the Stalinist years; the policy of opening up to the West was slowly gaining momentum. The only antidote seemed to be competition with this Western penetration. Gyula Kállai conceded that "the youth is not interested in or asking for the full exposition of Marxism but the satisfaction of their needs and adequate propaganda work in the meantime". He insisted that Hungarian propaganda continue to point out "the swinishness of imperialism", but this would obviously not be enough. Politburo member Lajos Méhes called attention to two strategies, one of which was surprising given the communists' officially antinational stance: he wanted the party's "agitation and propaganda to do an even better job of referring to our national sentiments and national self-esteem”. Méhes also wanted to improve the quality of Hungarian popular-music programming to offset the attraction of American musical broadcasts like Teenager Party. This was precisely what Washington wanted: the national idea, and westernizing popular culture, both produced by the communist governments themselves. The only thing better than Iron-Curtain youths' listening to Top of the Pops on RFE would be their tuning into domestic programming for the same sounds. At that time, Soviet programming still followed Voice of America's popular show Music USA, which had been aired for Soviet audiences since $1955 .{ }^{163}$

One Hungarian refugee recounted that he and a fellow student had listened to music on RFE in their university club every night. Indeed, rock music, including the Hungarians' domestic version of it, may have played a critical role in the formation of a quasi-autonomous public sphere. In optimistic accounts, it helped dismantle the party- state's legitimacy. ${ }^{164}$ There is little doubt that Hungarian youth used popular musical forms as a first line of resistance to communist indoctrination. In addition, music enhanced the appeal of the US at a time when communist propagandists were trying to destroy America's image with accusations of murderous imperialism. The appeal of popular music put pressure on the authorities who were no longer able to cut off the ample supply of Western radio programming. Moreover, as Anna Szemere has written, rock music emerged as a lucrative business, and "as such, highlighted and exacerbated the tensions between socialist values and policies and the profit-orientation of the state-run entertainment industry."165

Everyday life had overtaken the decision-makers. Kállai complained that if the party's youth magazine, Magyar Ifjúság, was still "a communist journal, I do not understand what communism means". He noted bitterly that the paper was "popu- 
larizing Western lifestyle without [any] critique [of] the West... We do not find a single socialist hero in it except the Beatles". ${ }^{166}$ In fact, this publication's cover regularly featured young girls in bikinis exhorting the youth to sign up for the communists' summer-work camps under the slogan "Proletarians of the World, Unite".

Károly Kiss, the hardliner who served as deputy president of the Presidential Council, a select organ of the communist parliament, was openly pushing for an exchange of ministers with the United States, which the Americans interpreted as a sign of important change. ${ }^{167}$ In 1965 , Kádár declared that he was "willing to travel anytime and anywhere" to mend fences. Although he was hoping to limit his anti-imperialist protests to the area of ideology, the Vietnam conflict was assuming the dimensions of an East-West conflict and impeding progress in bilateral relations. In suspending the normalization process, the Political Committee pointed out that its "main reason" for doing so was "the American aggression in Vietnam and its effect on the international situation". ${ }^{168}$ The Foreign Ministry pointed out that "because of the situation created by the Vietnamese policy of the United States[,] we must forego the restoration of normal relations for a while". ${ }^{169}$ Thus a geographically unrelated crisis in a remote corner of the globe would alter the course of the Cold War in Europe. Had Kádár been able to achieve this opening to the West in the early 1960s rather than a decade later, the collapse of Hungarian communism would very likely have come sooner, possibly pulling the entire Soviet bloc into crisis.

The US Legation mistakenly believed that the Hungarians were using the Vietnam conflict as an excuse and had actually cancelled the normalization talks as a way of finding out how much the US would be willing to "pay" for an agreement. ${ }^{170}$ At the same time, the legation informed the State Department that Budapest made the war in Vietnam a key factor in their bilateral relations, pointing out that the tone and magnitude of the communists' propaganda could hardly be reconciled with Hungary's stated intention to normalize relations. ${ }^{171}$ The Political Committee discussed the possibility of Hungarian government ministers' avoiding the American exhibition at the Budapest International Trade Fair and using the fair's opening statement to "condemn the aggression[s] in Vietnam and the Dominican Republic". ${ }^{172}$

While some party conservatives might have thought that the time had come to nip the western initative in the bud, reformers tried to block a reversion to isolationism. A key figure behind the drive to liberalize, Jenő Fock thought that financial talks should be pursued based on economic criteria. Interestingly, another reform-oriented functionary, Rezső Nyers, wanted to suspend the talks. Kádár came out in support of resuming the talks while simultaneously making "political attacks" on the Americans. He also disagreed with the idea of recalling Hungarians from scholarship programs in the US, and with the motion that prominent recipi- 
ents of new awards, like the ethnographer Gyula Ortutay, cancel their invitations. Kádár also rejected the idea that the world-renowned composer and musical pedagogist Zoltán Kodály use his upcoming visit to the US to lodge protests. Although he had no formal training in foreign-policy matters, Kádár's views were pronounced, and he usually prevailed. He held that in spite of the Vietnam war, relations with the US should be settled. He added that in order to do so, the allies (meaning the USSR) would have to be consulted. ${ }^{173}$ Kádár saw no reason to discriminate against American exhibitors or use the fair as a forum for anti-American propaganda. He asked rhetorically, "Who should go and when to the American exhibit? I have been working for years to take out the strong politics [from such matters] because it doesn't help us. The Hungarian soul likes the pen knife and goulash but doesn't like cutting rations." 174

American participation in the fair was a double-edged sword for party propagandists. On the one hand, it trumpeted the regime's newfangled policy of tolerance. On the other hand, it underscored the popularity of the United States. Internal surveys conducted a few years later revealed that one million people (ten percent of Hungary's population) visited the American exhibition each year. The luxury items exhibited there fed the perception that "America is the home of unlimited possibilities where one can make a quick fortune". ${ }^{175}$ The American legation in Budapest understood the regime's dilemma: the great success of the exhibition was proven by the "enthusiastic reaction" of the people, which suggested that their government had failed to persuade them to condemn the United States. As it basked in the glory of a successful fair, the government seemed likely to enhance its own popularity by opening its gates even wider to American cultural influences. ${ }^{176}$

There were many signs of the appeal of American soft power. "American machines and know-how made a positive impact"; 200 "enthusiastic students" had shown up at a movie screening organized by the American legation. ${ }^{177}$ American literature, theater, music, architecture, and technological and scientific feats were all well received. According to American reports, Hungarians read, watched, and listened to a wide variety of American novels and plays with unusual enthusiasm. American performers played in front of full houses, making it almost impossible to get tickets to see them. Sometimes these guest performances went sour: the Hungarians were fully in charge of invitations, thus many times "unknown" performers would represent American culture very poorly. ${ }^{178}$

Notes

Janos Radvanyi, Hungary and the Superpowers: The 1956 Revolution and Realpolitik (Stanford: Stanford University Press, Hoover Institution Press, 1972), 31. 
2 A Magyar Népköztársaság jegyzéke az Egyesült Államok budapesti követségének [Note by the People's Republic of Hungary to the US Legation in Budapest], May 1957. Magyar Országos Levéltár [MOL], Küm, XIX-J-1-j, USA tük, 4. doboz, 4/a, 002418/1.

3 MOL, küm, XIX-J-1-j, USA tük, 4. doboz, 4/bd.

$4 \quad$ Instruction by the State Department to American Diplomatic Missions, 5 December 1957. NARA, RG 59, General Records of the Department of State, 864.181/12-557.

5 The Chargé in Hungary (Ackerson) to the State Department, 29 October 1959. NARA, RG 59 General Records of the Department of State, 61164/10-2757.; FRUS, 1955-57, Vol. XXV, 679-84.

6 The Chargé in Hungary (Ackerson) to the Department of State, 14 November 1957. NARA, RG 59 General Records of the Department of State, 61164/11-1457.

7 Melinda Kalmár, Ennivaló és hozomány - A korai Kádár-korszak ideológiája [Food and Dowry - The Ideology of the Early Kádár Years] (Budapest: Magvetö, 1998).

8 FRUS, 1955-57, Vol. XXV, 685-90.

9 Radvanyi, Hungary and the Superpowers, 32-3.

10 Zádor Tibor ideiglenes ügyvivő Horváth Imre külügyminiszternek. Tárgy: a magyar-amerikai kereskedelmet gátló tényezők [Report by chargé ad interim Tibor Zádor to Minister of Foreign Affairs Imre Horváth. Subject: Factors Impeding US-Hungarian Trade], 31 December 1957. MOL, Küm, USA tük, XIX-J-1-j, 1. doboz, 005851.

11 Zádor jelentése Horváthnak, látogatás Malone szenátornál [Report by Zádor to Horváth on Visit to Senator Malone] MOL, Küm, USA tük, XIX-J-1-j, 12. doboz, 5/c, 0028/1958.

12 Zádor Tibor jelentése a Külügyminisztériumnak, filmbemutató tartásáról [Report to the Foreign Ministry by Zádor on Movie Screening], 28 February 1958. MOL, Küm, USA tük, XIX-J-1-j, 1947-1964, 140t., 26. doboz, 002065; Bartha János ideiglenes ügyvivő jelentése Sík Endre külügyminiszternek filmbemutató tartásáról [Report by chargé ad interim Bartha to Foreign Minister Sík on Movie Screening], ibid. 104/2, 1958.

13 Irányelvek a magyar-amerikai kapcsolatok alakításához, III. számú Politikai Osztály, Amerikai Referatúra [Guiding Principles for the Development of Hungarian-American Relations, III. Political Department, American Desk], 1958. január 16. MOL, Küm, XIX-J-1-j, USA tük, 11. doboz, $4 / \mathrm{b}$.

14 Joseph F. Harrington, and Bruce J. Courtney, Tweaking the Nose of the Russians: Fifty Years of American-Romanian Relations, 1940-1990 (New York: East European Monographs, 1991), 194-201.

15 The Chargé in Hungary to the department of State, 5 May 1958. NARA, RG 59 General Records of the Department of State, 611.64/5-958. Wadsworth, later Cabot Lodge inquired about the fate of political prisoners at Péter Mód, who promised to look into the matter. Eventually, on 13 March he refused to provide information on the basis of interference in Hungarian domestic affairs. See Tamás Magyarics, "Az Egyesült Államok és Magyarország, 1957-1967” [The United States and Hungary], Századok, 1996. No. 3, 573.

16 "Két összefoglaló a magyar-szovjet tárgyalásokról" [Two Summaries on Hungarian-Soviet Talks]. Published by Magdolna Baráth and István Feitl. Múltunk, 1993. No. 4, 82-185.

17 Idézi Magyarics, Az Egyesült Államok és Magyarország, 576.

18 Memorandum by the Department of State Policy Planning Staff, 11 July 1958. NARA, RG 59 General Records of the Deparment of State, Lot File 60D216, Box 2, Wilcox.

19 Lásd erről Radvanyi, Hungary and the Superpowers, 42-3. On September 2 the Political Committee the measures to be introduced against the US Ferenc Münnich declared that, "if it was in anyone's interest for the American representation to be here and to work with a large number of staff, it is the international enemy, the government of American imperialism. We needn't be bashful. The mission here is a spy center for them, which they will not liquidate... 
We are an independent sovereign state; no one should poke their nose here... Regarding the missions we have no interest for them to be here. Let us not court them they can go home if they want."

20 MOL, Küm, USA tük, XIX-J-1-j, 3. doboz, 4/a, 00941/5.

21 Ibid. The US published the reply.

22 Radvanyi, Hungary and the Superpowers, 49.

23 Memorandum by Wilcox and Elbrick to Murphy, 7 October 1958. NARA, RG 59 Records of the Department of State, Lot File 60D216, Box 1, Wilcox.

24 NARA, RG 59 Records of the Department of State, Decimal File 864.413/10-2358.

25 Az Egyesült Államok jegyzéke [Note by the US], 18 October 1958. MOL, Küm, XIX-J-1-j, USA tük, 6. doboz, 4/b, 005726.

26 A Magyar Népköztársaság válasza az 1958. október 18-i USA jegyzékre, [Reply by the Hungarian People's Republic to the October 18 Note of the United States], 21 October 1958. MOL, Küm, XIX-J-1-k, USA admin, 11. doboz, 4/b.

27 Despatch from the Legation in Hungary to the Department of State on the future of Mindszenty, 20 November 1958. FRUS, 1958-60, Vol. X, 54-9.

28 Feljegyzés az USA-val való kapcsolatok normalizálásáról [Memorandum on Normalization of Relations with the US], 30 October 1958. MOL, Küm, USA admin, XIX-J-1-k, 11. doboz, 4/b. In January 1960 Deputy Foreign Minister Géza Kardos prepared a memorandum which stated that a financial claims settlement with the US would result in a negative balance. Kardos asserted that the most valuable Hungarian claim, the restitution of property removed during the war, was "impeded by numerous legal obstacles". Including restitution a Hungarian claim of USD 17 million was matched by a US claim of 81 million dollars. Memorandum by Géza Kardos on Hungarian-American financial issues, 21 January 1960. MOL, Küm, USA tük, XIX-J-1-j, 6. doboz, 4/b, 001479.

30 Magyarics, Az Egyesült Államok és Magyarország, 583.

31 CIA National Intelligence Estimate, "Political Stability in European Satellites", NIE 12-59, 11 August 1959. FRUS, 1958-60, Vol. X, 100-2.

32 Letter by Charles Vanik to the Secretary of State, 31 March 1960. NARA, RG 59 General Records of the Department of State, Central File 1960-1963, 611. 64. Microfilm, roll 93. "[...] a penetration might be made in this part of the Soviet-dominated world to preserve and keep alive well-developed by silent affection for America. The hope for the restoration of democracy in this part of the world will be strengthened as a result of individual missions of American citizens visiting their relatives".

33 Theodore Papendorp Second Secretary to the Department of State, "Visiting Hungary", March 19 1961. NARA, RG 59 General Records of the Department of State, Central File 1960-1963, 611. 64, Microfilm, roll 93.

34 "The cows looked better groomed and happier than the workers". For Bailey's view see: The American Legation in Hungary to the Department of State, 10 August 1960. NARA, General Records of the Department of State, Decimal File, Internal Affairs of Hungary 1960-1963, Microfilm, roll 5; Francis Shor is cited in The American Legation in Budapest to the Department of State, 13 June 1961. Ibid. "Found somewhat to his surprise, a fairly substantial intellectual middle class - unhappy and by no means enthusiastic about the regime, but tending to accept it for the present". See Charles Wiley's view in The American Legation to the Department of State, 11 July 1961. Ibid. "The Hungarians did win a partial victory in 1956". See Nicholas Feld's opinion in The American Legation in Hungary to the Department of State, "Trip to Tihany", 3 August 1961. Ibid. According to Feld there was "much greater resistance of the Hungarians to forced indoctrination... Tihany still preserves some of its upper bourgeois atmosphere". On the impressions of American tourists see The American Legation to the 
Department of State, 23 November 1961. Ibid.; For the Christian Science Monitor correspondent see The American Legation in Hungary to the Department of State, 28 June 1962. Ibid. László Halász is cited in The American Legation in Budapest to the Department of State, 14 June 1965. Ibid. "There is general fear, cultural stagnation and except in showcase Budapest, a serious food shortage". Wall Street Journal is cited in Courtney-Harrington, Tweaking the Nose of the Russians, 217. Communists could "enjoy the merry-go-round of night clubbing, sailing and opera recitals".

35 Justin Faure, L’Ami Américain - La Tchécoslovaquie, enjeu de la diplomatie américaine 1943-1968 (Paris: Tallandier, 2004), 372-3.

$36 \quad$ Ibid. 69.

37 The American Legation in Budapest to the Department of State, "The Hungarian Economy in 1959", 27 January 1960. NARA, RG 59 General Records of the Department of State, Decimal File 1960-63, The Internal Affairs of Hungary, Microfilm, roll 3; The American Legation in Hungary to the Department of State, "The Hungarian Economy in 1961", 27 January 1962. Ibid.; The American Legation in Budapest to the Department of State, 3 August 1961. Ibid.; The American Legation in Hungary to the Department of State, 15 March 1962. Ibid.

38 The American Legation to the Department of State, 30 November 1962. NARA, RG 59 General Records of the Department of State, Internal Affairs of Hungary, Decimal File 764, Microfilm, roll 5.

39 Faure, L'Ami Américan, 350.

40 Joseph S. Nye Sr., Soft Power - The Means to Success in World Politics (New York, 2004), $12-13$.

41 The American Legation to the Department of State, for the USIA, 29 March 1962. Ibid.; The State Department to the Legation in Hungary, 7 September 1961. Ibid.; The American Legation to the Secretary of State, 22 June 1960, Ibid.; The Secretary of State (Herter) to the Legation in Hungary, 13 July 1960. Ibid.

42 "Bridgebuilding in Eastern Europe", Policy Planning Council, 31 July 1964. NARA, RG 59 Records of the Department of State, Lindley Files, Lot File 71D273, Box 4. "The US in Eastern Europe can draw upon considerable assets of goodwill [...] This fund of resources is perhaps unique throughout the region and unmatched by any Western country". In 1966 the Policy Planning Council asserted that the "US has the most prestige of any Western nation in Eastern Europe”. Highlight of Secretary's Policy Planning Meeting, 27 July 1966. Ibid. Box 5.

43 The American Legation to the Secretary of State, 24 August 1961. NARA, RG 59 General Records of the Department of State, Central File 1960-63, Internal Affairs of Hungary, Microfilm, roll 93.

44 The American Legation to the Department of State, Conversation with Hungarian Intellectuals, 12 April 1961. NARA, RG 59 General Records of the Department of State, Decimal File 764, Microfilm, roll 1.

45 Despatch from the Legation in Hungary to the Department of State, "Recommendations Regarding US Policy Toward Present Hungarian Regime, 23 January 1959. FRUS, 1958-60, Vol. X. 62-71.

46 Zádor Tibor jelentése Sík Endrének, látogatás Livingstone Merchantnél, az európai ügyek államtitkáránál [Report by Tibor Zádor to Endre Sík on Visit to Livingstone Merchant], 17 February 1959. MOL, Küm, XIX-J-1-j, USA tük, 15. doboz, 5/e, 001867.

47 A typical memorandum by the Ministry of Foreign Affairs asserted that "After the war American imperialism significantly sidelined the traditional colonialist countries and took their place and showed an unprecedented example of colonial exploitation... In order to assure colonial exploitation and to preserve its position as the leading Western power the United States... announced a struggle against communism and the progressive forces of the world." 
At the same time the huge scientific and technological results of the Soviet Union and the ever broader and stronger freedom struggle of colonial peoples has shown that Dulles's foreign policy is untenable." Memorandum by the American Desk, "The Foreign Policy of the United States and Hungarian-American Relations”, 30 November 1959. MOL, Küm, XIX-J-1-j, USA admin., 11. doboz, 4/bd.

48 Radvanyi, Hungary and the Superpowers, 84-5.

49 Bitta István feljegyzése Zádor Tibornak [Memorandum by István Bitta to Tibor Zádor], 13 March 1959. MOL, Küm, USA tük, XIX-J-1-j, 15. doboz, 5/e; A III. sz. politikai osztály javaslata a magyar-amerikai kapcsolatok javítására [Memorandum by the III. Political Department for the Improvement of Hungarian-American Relations], 2 April 1959. Ibid. 001479 .

50 The US banned the import of meat products from Hungary in 1938 because of the foot and mouth disease. After the war Hungary sought to sign a new animal health treaty with the US but this could not be done because of the political situation. This seemingly insignificant issue remained unresolved even two decades after the war.

51 Az MSZMP KB Külügyi Osztályának előterjesztése az MSZMP KB Politikai Bizottságának (Sík Endre, Hollai Imre) [Memorandum by the Foreign Affairs Department of the HSWP Central Committee to the Political Committee of the HSWP Central Committee], 26 February 1960. MOL, KS, 288. f., 5. cs., 172. őe.

52 In October 1959 the Hungarian foreign minister told Bruno Kreisky that if Austria had a concrete proposal for the Cardinal's release, Hungary would give it consideration. The US indicated to Kreisky that it would welcome a solution which would give Mindszenty safe passage out of Hungary in case it was acceptable to the Vatican and the Cardinal. Kreisky sent the American position to the Vatican through the papal nuncio in Vienna. Memorandum from the Deputy Assistant Secretary of State for European Affairs (Kohler) to Secretary of State Herter, 1959. december 9. FRUS, 1958-60, Vol. X, 104-6. At this point Kreisky's mediation effort seems to have petered out.

53 Az MSZMP KB Külügyi Osztályának előterjesztése az MSZMP KB Politikai Bizottságához, Javaslatok a Mindszenty-kérdés rendezésével kapcsolatban [Recommendation by the Foreign Affairs Department of the HSWP Central Committee to the Political Committee of the HSWP CC], 25 March 1960. MOL, KS, 288. f., 5. cs., 176. őe.

54 Az MSZMP KB Külügyi Osztályának előterjesztése a Politikai Bizottságnak a magyaramerikai viszony normalizálásáról [Recommendation by the Foreign Affairs Department of the HSWP Central Committee to the Political Committee of the HSWP CC on the Normalization of Hungarian-American Relations],12 May 1960. MOL, 288. f., 5 cs, 183. őe.

55 Memorandum of Conversation, 27 April 1960. Participants: Joseph Mileger, Harold Vedeler, Robert McKisson. NARA, RG 59 Records of the Department of State, Central File, 1960-63, Internal Affairs of Hungary, Microfilm, roll 93.

56 Anatoly Dobrynin, In Confidence - Moscow's Ambassador to America's Six Cold War Presidents (1962-1986) (New York: Times Books, 1995), 40-1.

57 The Foreign Ministry thought it unlikely that the US would make an initiative because Soviet-American relations had deteriorated. The ministry also pointed out that there was no realistic chance for the relaxation of export controls since that would require an act of Congress. Memorandum by the III $^{\text {rd }}$ Territorial Department, 11 August 1960. MOL, Küm, USA admin, XIX-J-1-k, 11. doboz, 4/bd.

58 Instruction from the Department of State to the Legation in Hungary, 21 October 1960. FRUS, 1956-60, Vol. X, 126-30.

59 Foy Kohler to the Secretary of State regarding US-Hungarian Relations, 26 January 1961. NARA, RG 59 Records of the Department of State, Central File 611.64, Microfilm, roll 93. 
60 The American Legation in Budapest to the Department of State, 1960. NARA, RG 59 Records of the Department of State, Central File 611.64, Microfilm, roll 93.

61 Memorandum by Foy Kohler, Woodruff Wallner to the Secretary of State (Herter), 21 February 1961. NARA, RG 59 Records of the Department of State, Internal Affairs of Hungary, 1960-1963. Microfilm, roll 1.

62 Sík Endre feljegyzése Biszku Bélának [Memorandum by Endre Sík to Béla Biszku], 14 April 1961. MOL, Küm, USA tük, XIX-J-1-j, 4. doboz 4/a, 001745/61.

63 Zádor Tibor jelentése Sík Endrének, Beszélgetés Vedelerrel, a State Department főosztályvezetőjével [Report by Tibor Zádor to Endre Sík, Conversation with State Department Head Harold C. Vedeler], MOL, KÜM, XIX-J-1-j, 15. doboz, 5/e, 003499/1.

64 Péter János feljegyzése Biszku Bélának [Memorandum by János Péter to Béla Biszku], MOL, KÜM, USA tük, XIX-J-1-j, 4. doboz, 4/a, 001745/1961.

65 Courtney - Harrington, Tweaking the Nose of the Russians, 221-2.

66 Memorandum of Conversation, US-Hungarian Relations, 5 April 1961. NARA, RG 59 Records of the Department of State, Political Relations Between the US and Hungary, 1960-1963, Microfilm, roll 93.

67 Telegram from New York (Yost) to the Secretary of State, 5 June 1961. NARA, RG 59 Records of the Department of State, Hungary 1960-1963, Microfilm, roll 1.

68 Telegram from New York to the Secretary of State, 25 May 1961. Ibid.

69 Radvanyi, Hungary and the Superpowers, 84-6; Magyarics, Az Egyesült Államok és Magyarország, 583.

70 Rusk to the American Legation in Hungary, 2 August 1961. NARA, RG 59 Records of the Department of State, Hungary 1960-1963, Microfilm, roll 1.

71 Memorandum of Conversation, 3 August 1961. Ibid.

72 Telegram from Budapest, 4 August 1961. Ibid.

73 A IV. Területi főosztály Amerikai Referatúrájának feljegyzése Szőke György számára [Memorandum by the American Desk of the IV ${ }^{\text {th }}$ Territorial Department for György Szőke], 4 January 1962. MOL, Küm, USA tük, XIX-J-1-j, 11. doboz, 4/bd.

74 Memorandum of Conversation, 13 June 1963. Participants: Chester Bowles, Radványi János, NARA, RG 59 Records of the Department of State, Hungary 1960-1963, Political Relations Between the US and Hungary 1960-1963, Microfilm, roll 93.

75 Telegram by George Ball to New York, 12 June 1962. Ibid. roll 2.

76 Telegram by Rusk, August 1962. Ibid.

77 The American Legation to the Department of State, Conversation with Szarka, 12 September 1961. NARA, RG 59 Records of the Department of State, Hungary 1960-1963, Political Relations Between the US and Hungary 611.64, Microfilm, roll 93; The American Legation in Hungary to the Department of State, 14 September 1961. Ibid.

78 The Legation in Hungary to the Secretary of State, Conversation with Kádár, 29 September 1961. NARA, RG 59 Records of the Department of State, Hungary 1960-1963, Decimal File 764, Microfilm, roll 3.

79 The American Legation to the Department of State, 2 October 1961. Ibid.

80 Letter by Roger Tubby, Assistant Secretary for Public Affairs to Béla Király, Hungarian Freedom Fighters Federation, 20 October 1961. Ibid. Roll 1. "Hungarian patriots bravely struggled against tremendous odds to win national independence and freedoms to which all mankind and all nations are entitled [...] free men everywhere will pay tribute to the valor of the Hungarian people and reaffirm their respect for Hungary's struggle against Soviet imperialism. The free world will not forget the sacrifices of the Hungarian people."

81 The American Legation to the Secretary of State, 19 October 1961. NARA, RG 59 Records of the Department of State, Hungary 1960-1963, Political Relations Between the US and 
Hungary 611.64, Microfilm, roll 93; The Acting Secretary of State (Bowles) to the US Legation in Hungary, 23 November 1961.

82 The State Department to the Legation in Hungary, 16 January 1962. NARA, RG 59 Records of the Department of State, Hungary 1960-1963, Political Relations Between the US and Hungary 611.64 1960-1963, Microfilm, roll 93.

83 The American Legation in Hungary to the Secretary of State, February 1962. NARA, RG 59 Records of the Department of State, Hungary 1960-1963, Microfilm, roll 1.

84 The American Legation to the Department of State, New US Desk Officer in Hungary, 2 November 1961. NARA, RG 59 Records of the Department of State, Hungary 1960-1963, Political Relations Between the US and Hungary, 1960-1963, Microfilm, roll 93; The American Legation to the Department of State, Radványi Transfer, 15 February 1962. Ibid.

85 Memorandum of Conversation, Radványi, Zádor, Kohler, Davis, Trost, 21 February 1961. Ibid.

86 Zádor Tibor jelentése Péter Jánosnak, Amerikai külügyi tisztviselők meghívása [Report By Tibor Zádor to János Péter, invitation of State Department officials], 23 January 1962. MOL, Küm, USA tük, XIX-J-1-j, 15. doboz, 5/e, 001234.

87 Radvanyi, Hungary and the Superpowers, 92-3. According to Radványi Kádár told him that until the Americans insisted on the amnesty as a precondition of improvement the amnesty would not take place.

88 Radványi János jelentése Péter Jánosnak [Report by János Radványi to János Péter], 24 March 1962. MOL, Küm, USA tük, XIX-J-1-j 15. doboz, 001224/13.

89 A Külügyminisztérium feljegyzése [Memorandum by the Foreign Ministry], 16 April 1962. MOL, Küm, USA tük, XIX-J-1-j, 15. doboz, 01224/2.

90 Memorandum of Conversation, 26 April 1962. Participants: Radványi, McGhee, McKisson. NARA, RG 59 Records of the Department of State, Political Relations Between Hungary and the United States Microfilm, reel 93.

91 Radványi János jelentése Péter Jánosnak, McGhee államtitkárral folytatott megbeszélés [Report by Radványi to Péter, Conversation with McGhee], 29 April 1962. MOL, Küm, USA tük, XIX-J-1-j, 15. doboz, 5/e, 05115.

92 Rácz Pál Radványi Jánosnak, Beszélgetés McGheevel, 1962. május 24. MOL, Küm, XIX-J-1-j, 15 doboz, 5/e, 005115.

93 Polgár Dénes feljegyzése, 1962. május 21. és Radványi János jelentése [Memorandum by Dénes Polgár, 21 May 1962 and Report by János Radványi, 25 May 1962]. MOL, Küm, USA tük, XIX-J-1-j, 15. doboz, 5/e, 005413. American diplomacy used Dénes Polgár as a kind of back channel to the Hungarian leadership. Since the Political Committee referred to a report by Polgár it is evident that he was used to circumvent the Ministry of Foreign Affairs.

94 The American Legation in Budapest to the Secretary of State, 31 May 1962. NARA, RG 59 Records of the Department of State, Political Relations between Hungary and the United States, 611.64, 1960-63, Microfilm, roll 93.

95 Ibid.

96 Memorandum of Conversation, 13 Februar 1962. Participants: Edigio Vagnozzi, Harold C. Vedeler, August Velletri. FRUS, 1961-63, Vol. XVI, 14-16.

97 Memorandum of Conversation, Situation of Mindszenty, 2 May 1962. Participants: Edigio Vagnozzi, Harold C. Vedeler, August Velletri. Ibid. 22-3.

98 Jegyzőkönyv az MSZMP KB Politikai Bizottságának üléséről [Record of the Meeting of the HSWP Political Committee], 7 August 1962. MOL, KS 288. f., 5. cs., 274. őe.

99 Ibid. Előterjesztés az MSZMP KB Politikai Bizottságának. Határozati javaslat a magyaramerikai viszony normalizálásáról és a Mindszenty-ügyről folytatandó tárgyalások kérdésében [Recommendation to the HSWP Political Committee. Draft Resolution on the Normaliza- 
tion of Hungarian-American Relations and Regarding Talks concerning Mindszenty], $10 \mathrm{Au}-$ gust 1962. Ibid. 275. öe. Polgár reported that Turner Shelton would come with detailed instructions regarding the normalization talks.

The American Embassy in Stockholm to the American Legation in Budapest, 21 January 1961. NARA, RG 59 General Records of the Department of State, Political Relations Between the US and Hungary, 1960-1963, Microfilm, roll 93; The Department of State to the Embassy in Stockholm, 29 January 1960. Ibid.

101 Torbert to the Department of State, 14 March 1961. Ibid. John F. Kennedy to Cardinal Mindszenty, 2 February 1961. Ibid.

102 NARA, RG 59 Records of the Department of State, Internal Affairs of Hungary 1960-1963, Microfilm, roll 5.

103 Memorandum of Conversation - Situation of Cardinal Mindszenty, Participants: Vagnozzi, Vedeler, 2 May 1962. Ibid.

104 Radványi János összefoglalója Péter János külügyminiszternek [Summary by Radványi for Foreign Minister János Péter], 11 September 1962. MOL, Küm, XIX-J-1-j, USA tük, 6. doboz, $001224 / 6$.

105 Telegram from New York to the Secretary of State, 15 May 1962. NARA, RG 59 Records of the Department of State, Internal Affairs of Hungary 1960-1963, Microfilm, roll 2.

106 Memorandum of Conversation, 1 September 1962. Participants: Radvanyi, Vedeler, Davis. NARA, RG 59 Records of the Department of State, Political Relations between Hungary and the United States, Microfilm, roll 93.

107 Memorandum of Conversation, 26 September 1962. Participants: Kreisky, Rusk. NARA, RG 59 Records of the Department of State, Internal Affairs of Hungary, 1960-1963, Microfilm, roll 2.

108 Telegram to the Secretary of State, 26 September 1962. Ibid.

109 Az amerikai Külügyminisztérium emlékeztetője a magyarkérdés és az amnesztia tárgyában [Memorandum by the State Department regarding the Hungarian Question and the amnesty], 20 October 1962. MOL, Küm, XIX-J-1-j, USA tük, 4/bd, 6. doboz; [Report by Radványi regarding the State Department Memorandum], 7 November 1962. Ibid. 001224/8/1962.

110 Hope Harrison, Driving the Soviets Up the Wall-Soviet-East German Relations, 1953-1961 (Princeton University Press, 2003).

111 Radvanyi, Hungary and the Superpowers, 140-1.

112 The American Legation in Hungary to the Secretary of State, 24 November 1962. NARA, RG 59 Records of the Department of State, Political Relations between Hungary and the United States, 611.64, 1960-63, Microfilm, reel 93.

113 Radványi jelentése Péter Jánosnak [Report by Radványi to Péter], 21 December 1962. MOL, Küm, XIX-J-1-j, USA tük, 6. doboz, 00598.

114 Jonathan Haslam, Russia's Cold War-From the October Revolution to the Fall of the Wall (New Haven and London: Yale University Press, 2011), 229-30.

115 Geraint Hughes, Harold Wilson's Cold War - The Labour Government and East-West Conflict 1964-1970 (The Royal Historical Society, 2009), 39.

116 Bennet Kovrig, Of Walls and Bridges: The United States and Eastern Europe, (New York University Press, 1991) 107-8.

117 "The Bloc Countries and Eastern-Europe", Department of State Guidelines for policy and Operations, February 1963. NARA, RG 59 General Records of the Department of State, Executive Secretariat, 1961-1966, Box 5.

118 Courtney - Harrington, Tweaking the Nose of the Russians, 252.

119 Courtney - Harrington, Tweaking the Nose of the Russians, 268.

120 Special Report by the CIA, 27 March 1964. FRUS, 1964-68, Vol. XVII, 2-8. 
121 "Changing Patterns in Eastern Europe", submitted by the Director of CIA, concurred by the US Intelligence Board, National Intelligence Estimate 12-64, 22 July 1964. NARA, RG 59 Records of the Department of State, Policy Planning Council, Lot File 70D199, 1963-64, Box 260. "East European leaders are increasingly free to approach these questions in light of national aspirations and local political conditions".

122 NARA, RG 59 Records of the Department of State, Policy Planning Council Lot File 70D199, Box 260.

123 "Changing Patterns in Eastern Europe". Op. cit.

124 "The Situation in Eastern Europe", The Director of Research and Intelligence of the Department of State to the Acting Secretary of State, 16 April 1964. NARA, RG 59 Records of the Department of State, PPC, Lot File 70D199 1963-64, Box 260.

"Eastern Europe's involvement in Communist Conspiratorial Activities", Director of Research and Intelligence of the Department of State, 9 July 1964. NARA, RG 59 Records of the Department of State, PPC, Lot File 70D199 1963-64, Box 260.

126 "Changing Patterns in Eastern Europe". Op. cit.

127 "Bridgebuilding in Eastern Europe", 31 July 1964. Op. cit.

128 Courtney - Harrington, Tweaking the Nose of the Russians, 230.

129 NSAM 304, Action program for US Relations with Eastern Europe, August 1964. NARA, RG 59 Records of the Department of State, PPC, Lot File 70D199 1963-64, Box 260.

130 "The US and East-West Relations in Europe", Memorandum by the Department of State, 3 August 1963. NARA, RG 59 Records of the Department of State, Ernest K. Lindley Files 1961-1969, Lot File 71D273, Box 4.

131 Hughes, Harold Wilson's Cold War, 44-7.

132 Memorandum of Conversation, "The Hungarian Situation and US-Hungarian Relations", 10 September 1964. Participants: Ferenc Nagy, Béla Varga, Richard H. Davis, Harold C. Vedeler, Robert B. Wright, Robert McKisson, Christopher Squire. NARA, RG 59 Records of the Department of State, Central Files 1964-66, Box 2275.

133 Faure, Ami Américain, 336.

134 The Director of the Department of State Research and Analysis Branch to the Acting Secretary of State, 16 April 1964. Op. cit.

135 "Changing Patterns in Eastern Europe", NIE 12-64, 22 July 1964. Op. cit.

136 Owen T. Jones to the Secretary of State: Political Assessment of Hungary 1964. NARA, RG 59 Central Files, 1964-1966, Hungary, Box 2275.

137 János M. Rainer, "The Sixties in Hungary - Some Historical and Social Approaches," in János M. Rainer and György Péteri (eds), Muddling Through the Long 1960s. Ideas and Every Day Life in High Politics and the Lower Classes of Communist Hungary (Trondheim Studies on East European Cultures and Societies, Budapest - Trondheim, 2005), 4-26. Sándor Horváth, "Hooligans, Spivs and Gangs - Youth Subcultures in the 1960s." Ibid. 199-223.

138 A Magyar Forradalmi Munkás-Paraszt Kormány 3062/1964 számú határozata [Resolution Number 3062/1964 by the Hungarian Revolutionary Workers Peasants Government] 19 February 1964. MOL, Küm, XIX-J-1-j, USA tük, 6. doboz, 4/b 002812; A Külügyminisztérium jegyzéke [Memorandum by the Foreign Ministry], 24 February 1964. Ibid.

139 The American Legation in Budapest to the Secretary of State, 26 February 1964. NARA, RG 59 Records of the Department of State, Central Files 1964-66, Hungary, Box 2277.

140 Memorandum of Conversation, Retention of Soviet Armed Forces in Hungary, 21 January 1964. Participants: R. Heath Mason, Counsellor of British Embassy; Harold C. Vedeler. Ibid.

141 The Legation in Hungary to the Department of State, 18 July 1964. Ibid.

142 Memorandum from the President's Special Assistant for National Security (Bundy) to President Johnson, 14 April 1964. FRUS, 1964-68, Vol. XVII, 301. 
143 The American Legation in Budapest to the Secretary of State, 8 December 1964. NARA, RG 59 Records of the Department of State, Central Files 1964-66, Hungary, Box 2278.

144 A Külügyminisztérium feljegyzése a magyar-amerikai tárgyalásokról [The Foreign Ministry's Memorandum on Hungarian-American Talks], 18 February 1964. MOL, KS 288. f., 5. cs., 327. őe. Memorandum of Conversation, Claims Settlement, 30 November 1964. NARA, RG 59 Records of the Department of State, Central Files 1964-66, Hungary, Box 2278.

145 János Honvári, "Gazdasági kapcsolatok Magyarország és az USA között 1945-1978” [Economic Relations Between the US and Hungary] Századok, 143. évf., 1. sz. (2009), 43-4; 47; 55.

146 Csaba Békés, “A Kádári külpolitika 1956-1968: Látványos sikerek - «láthatatlan konfliktusok»" [Kádár's Foreign Policy - Spectacular Successes, 'Invisible Conflicts'] in Békés, Európából Európába: Magyarország konfliktusok kereszttüzében, 1945-1990 [From Europe to Europe: Hungary in the Crossfire of Conflicts] (Budapest: Gondolat, 2004) 245-6. Hungarian-West German relations after 1963 are another example for the economic motivations of the policy of opening up.

147 Jegyzőkönyv az MSZMP KB Politikai Bizottságának üléséről. Előterjesztés az Egyesült Államok külügyminiszterével folytatandó tárgyalásokkal kapcsolatban [Record of the Meeting of the HSWP CC Political Committee. Recommendation Regarding Negotiations with the Secretary of State of the United States], 26 November 1964. MOL KS 288. f., 5. cs., 352. öe.

148 Péter-Rusk találkozó [Péter-Rusk Meeting], 4 December 1964. MOL, Küm, XIX-J-1-j, USA tük, 6. doboz, 4/b, 116612/1964; Memorandum of Conversation, New York, Secretary's Delegation to the $19^{\text {th }}$ Session of the UNGA. Participants: Secretary, Mr Givan, Péter, Radványi. FRUS, 1964-68, Vol. XVII, 305-6.

149 Jegyzőkönyv az MSZMP PB Politikai Bizottságának üléséről [Record of the Meeting of the Political Committee of the HSWP CC], 29 October 1963. MOL, KS 288. f., 5. cs., 318. őe.

150 Telegram form the Legation in Hungary to the Department of State, 11 March 1964. FRUS, 1964-68, Vol. XVII, 299-300.

151 Jegyzőkönyv az MSZMP KB Politikai Bizottságának 1965. szeptember 14-én megtartott üléséról [Record of the Meeting of the Political Committee of the HSWP CC held on 14 September 1965]. MOL, KS 288. f., 5. cs., 37. őe. See also MSZMP KB Politikai Bizottságának ülése [Meeting of the Political Committee], 29 October 1963. Ibid. 318. őe.

152 Radványi jelentése a Külügyminisztériumnak [Report by Radványi to the Foreign Ministry], 26 September 1965. MOL, Küm, XIX-J-1-j, USA tük, IV-14, 13. doboz, 004704/1965.

153 Radványi jelentése a külügyminisztériumnak [Report by Radványi to the Foreign Ministry], 13 October 1965. Ibid. The American record is brief. It does not contain any reference to the position of the Vatican or the American statement that the Hungarians could achieve moral victory by letting Mindszenty go. The Department of State to the Legation in Hungary, 2 October 1965. NARA, RG 59 Records of the Department of State, Central Files, Box 2182.

154 Honvári, Gazdasági kapcsolatok Magyarország és az USA között, 60-1.

155 Courtney and Harrington, Tweaking the Nose of the Russians, 270.

156 Memorandum by the USIA (Edward R. Murrow) to W. A. Harriman, 16 September 1963. Library of Congress Manuscript Division, Papers of Averell Harriman, Box 470.

157 Faure, Ami Américain, 347.

158 Faure, Ami Américain, 346.

159 Tervezet - Előterjesztés az Ügyvezető Elnökség részére a Ford Ösztöndíj tapasztalatairól [Draft - Recommendation by the Institute of Cultural Relations to the Interim Presidium on the Experiences of the Ford Scholarship], 30 September 1967. MOL, Kulturális Kapcsolatok Intézete, XIX-A-33-a, USA-6022-1968, 217. doboz.

160 NSAM 304, 4 August 1964. Op. cit. 
161 Az MSZMP KB Politikai Bizottságának ülése [Meeting of the Political Committee of the HSWP CC], 23 November 1965. MOL, KS, 288. f., 5. cs., 380. őe.

162 Az MSZMP KB Politikai Bizottságának határozata [Resolution by the Political Committee of the HSWP CC], 26 April 1966. MOL, KS, 288. f., 5 cs., 393. őe.

163 Walter Hixson, Parting the Iron Curtain: Propaganda, Culture and the Cold War, 1945-1961 (London: MacMillan, 1997) 114-15.

164 See Anna Szemere, Up from the Underground - The Culture of Rock Music in Postsocialist Hungary (Pennsylvania: The Pennsylvania University Press, 2001).

165 Ibid. 11.

166 Az MSZMP KB Politikai Bizottságának ülése, 1965. november 23. [Meeting of the Political Committee of the HSWP CC, 23 November 1965.]

167 The American Legation in Hungary to the Department of State, Discussion with Károly Kiss, 16 March 1964. NARA, General Records of the Department of State, Central Policy File 1964-1966, Political Affairs and Relations, Box 2279.

168 Előterjesztés az MSZMP KB Politikai Bizottsága számára [Recommendation for the Political Committee of the HSWP CC], 26 April 1966. MOL, KS 288. f., 5. cs., 393. öe.

169 A Külügyminisztérium V. Területi Főosztályának előterjesztése [Recommendation by the Vth Territorial Department of the Ministry of Foreign Affairs], undated [1965]. MOL, Küm, XIX-J-1-j, USA tük, 12. doboz, 5 b/t sz. n. 1965.

170 The American Legation in Hungary, US Policy Assessment, 9 February 1966. NARA, General Records of the Department of State, Central Policy File 1964-1966, Political Affairs and Relations, Box 2278.

171 Airgram from the Legation in Hungary to the Department of State 31 August 1965. FRUS, 1964-68, Vol. XVII, 308-10.

172 Jegyzőkönyv az MSZMP KB Politikai Bizottságának 1965. május 11-én megtartott üléséről [Record of the Meeting of the Political Committee of the HSWP CC held on 11 May 1965]. MOL KS 288. f., 5. cs., 365. őe.

173 Jegyzőkönyv az MSZMP KB Politikai Bizottságának 1965. szeptember 14-én megtartott üléséröl [Record of the Meeting of the Political Committee of the HSWP CC], 14 September 1965. MOL, KS, 288. f., 5. cs, 37. őe. As Kádár put it: "Why do the Americans wish to settle their relations with Hungary? This is an old line of theirs, they have been trying to prove for over eighteen months now that they support peaceful coexistence while they are bombing Vietnam and in the meantime they wish to settle their relations with us. This somehow falls into our political line although we must inform our allies."

174 Jegyzőkönyv az MSZMP KB Politikai Bizottságának 1965. május 11-én megtartott üléséről [Record of the Meeting of the Political Committee of the HSWP CC held on 11 May 1965]. Op. cit.

175 Feljegyzés az amerikai gazdasági propagandáról [Memorandum on American economic propaganda], undated [1972]. MOL, KS, 288. f., 5. cs., 34. őe.

176 The American Legation (Tims) in Hungary to the Department of State, 5 August 1965. NARA, RG 59 General Records of the Department of State, Central File 1964-1966, Political Affairs and Relations, Box 2278.

177 Memorandum by the USIA to the President (Nixon), 14 May 1969. NARA, Nixon Presidential Materials, Institutional H Files 1969-1974, Box H-133., The American Embassy to the Secretary of State, 20 December 1969. NARA, RG 59 General Records of the Department of State, Central File 1969-1969, Box 2181.

178 The American Embassy in Hungary to the Secretary of State, "US Policy Assessment: Hungary", 10 January 1969. NARA, RG 59 General Records of the Department of State, Central File 1969-1969, Box 2183. 